\title{
Profesní identita studentek učitelství pro mateřské školy a její odraz v portfoliu
}

\author{
Veronika Rodová, Zora Syslová \\ Masarykova univerzita, Pedagogická fakulta, Katedra primární pedagogiky
}

Redakci zasláno 16. 8. 2020 / upravená verze obdržena 1.3. 2021 /

/ k uveřejnění přijato 13. 4. 2021

\begin{abstract}
Abstrakt: Předložená studie přináší pohled na portfolio a jeho místo v reflektivně pojatém př́pravném vzdělávání učitelů mateřských škol na Pedagogické fakultě Masarykovy univerzity. Cílem studie je přispět k diskuzi o profesionalizačním pojetí přípravy učitelů mateřských škol s využitím akčního výzkumu výukových strategií a jejich vlivu na proces profesního rozvoje studentek. Úvodní část studie je věnována teorii učitelského vzdělávání a analýze klíčového pojmu portfolio, která se opírá o přehledovou studii českých i zahraničních zdrojů. Jádro studie tvoří akční výzkum zaměřený na sledování vlivu kurzu Tvorba profesního portfolia na rozvoj profesní identity studentek. Výsledky studie prezentují, jak kooperativní aktivity a vrstevnické hodnocení rozvíjejí interpersonální dovednosti studentek, podporují jejich sebedůvěru a prohlubují porozumění funkci portfolia jako prostředku sebevyjádření a jejich profesního růstu. Nad rámec akčního výzkumu studie přináší čtyři individualizované portréty studentek, které využily portfolia při státní závěrečné zkoušce.
\end{abstract}

Klíčová slova: portfolio, student, reflektivně pojaté přípravné vzdělávání, profesní rozvoj, akční výzkum, sociokonstruktivismus

Představitelé školské politiky i odborná veřejnost vyspělých zemí světa věnují od konce minulého století stále větší pozornost předškolnímu vzdělávání, zejména pak jeho kvalitě. V současnosti je předškolní vzdělávání celosvětově uznávané jako první velmi důležité společenské prostředí, se kterým se dítě setkává mimo nejbližší rodinu (např. Sylva et al., 2004; Yoshikawa et al., 2013). V souvislosti s tím se mění pohled na profesi učitele mateřské školy i na podobu přípravného vzdělávání. Historie př́ípravy na tuto učitelskou profesi se liší od přípravného vzdělávání učitelů vyšších stupňů škol. Je to dáno tím, že role učitelů mateřských škol nebyla v minulosti rolí vzdělavatelskou. Charakter prvních institucí určených dětem předškolního věku byl zejména pečovatelský. Není proto náhodou, že v českých zemích byly ženy v těchto institucích označovány do roku 1934 jako pěstounky. ${ }^{1}$

1 Výnos ministerstva školství a národní osvěty ze 17. února 1934, č. 141.800/33-III/5.

https://doi.org/10.5817/PedOr2021-1-35 
V dnešní době je profese učitele mateřské školy považovaná za rovnocennou ostatním učitelským profesím s respektem ke specifikům vzdělávání dětí tohoto věku. Ve vyspělých zemích je pro přípravu na tuto profesi požadováno vysokoškolské vzdělání. Česká republika tvoří výjimku, nebot' je zde dosud dostačující středoškolské vzdělání. Přesto procento vysokoškolsky vzdělaných učitelů mateřských škol vzrůstá. Pedagogické fakulty nabízí pregraduální studijní programy pro učitele mateřských škol. Diskuze vedená o jejich podobě a kvalitě je často spojována s úvahami o kvalitě studijních programů učitelství pro 1. stupeň ZŠ.

Naší snahou proto bylo přispět k diskuzi o profesionalizačním pojetí přípravy učitelů (Spilková, 2019) s využitím výzkumného pohledu na portfolio jako prostředek prohlubující se učitelské způsobilosti, názorových a vztahových proměn a pojmenovaných bodů zlomu v profesionalizačním př́běhu (Lukášová et al., 2014). Doufáme, že předložený text svými nálezy z akčního výzkumu obohatí diskuzi o podobě konkrétních strategií a jejich efektivitě ve studijních programech učitelství pro mateřské školy.

\section{Teoretické zakotvení studie}

V následující kapitole bychom rády představily rámec, ze kterého vycházíme ve studijním programu Učitelství pro mateřské školy na Pedagogické fakultě Masarykovy univerzity a který ovlivnil náš př́stup k akčnímu výzkumu. Věnujeme se v něm také představení našich výukových strategií v konkrétním kurzu zaměřeném na tvorbu portfolia. ${ }^{2}$

\subsection{Teorie učitelského vzdělávání}

Pedeutologická témata se stávají ve stále větší míře jádrem odborných statí i publikací. Shoda panuje v odklonu od akademického ke kompetenčnímu pojetí učitelského vzdělávání, ne už tolik v konkrétních způsobech a podobě vysokoškolské výuky (Kasíková, 2015a, s. 46). Spilková (2019, s. 271) upozorňuje na střetávání paradigmat, kdy v praxi vysokoškolské přípravy učitelů často přetrvává akademický přístup, který upřednostňuje obsah a obecné, abstraktní poznatky jako základ učitelské přípravy. Kompetenční model, stejně jako akademický, má kromě stoupenců také své odpůrce. Nemáme ambici vnášet do těchto sporů další pohled. Chceme zde však vymezit zorný úhel,

2 Kromě jiného považujeme za důležité, aby student získal zkušenost se zpracováním portfolia tak, aby ji bylo možné využít při zpracování diagnostických portfolií dětí v budoucí profesi. 
z jakého na problematiku vysokoškolské přípravy učitelů mateřských škol nahlížíme.

V souladu se Spilkovou (2019, s. 275) vnímáme tzv. profesionalizační koncepci učitelské přípravy za nosné pojetí, které propojuje silné stránky obou předchozích, bipolárně chápaných paradigmat (akademického a kompetenčního). V profesionalizačním procesu jde o upevňování profesní identity, tj. uvědomování si podstaty profese a vlastních profesních dovedností, přebírání odpovědnosti za svůj profesní rozvoj, přiměřenou potřebu sebekontroly (Dytrtová \& Krhutová, 2009; Stuchlíková, 2006). Spilková a kol. (2004, s. 147-149) rozlišili tři fáze vývoje profesní identity budoucího učitele (tabulka 2). Klíčovým pojmem v procesu profesionalizace studenta se stává $a u$ toregulace. Její součástí jsou zvnitřněné procesy autonomního sebehodnocení, které dokládají výsledky profesionalizační cesty studenta v jeho portfoliu a současně také seberozvojové náměty budoucích profesních činností. Jinými slovy student rozvíjí strategie poznávání vlastního profesního rozvoje tak, aby se mohl aktivně sám zdokonalovat (Lukášová et al., 2014, s. 11).

Této koncepci odpovídá multioborové studium, jakým učitelství pro mateřské školy bezesporu je. Východiskem pro koncepci přípravného vzdělávání učitelů mateřských škol se stávají základní charakteristiky této profese, které podrobně rozpracovala Burkovičová (2012). Profesní činnosti učitele mateřské školy se odvíjí od požadavků, jaké jsou kladeny na předškolní vzdělávání. V profesních dovednostech učitele mateřské školy můžeme vidět jakousi paralelu s požadavky, jaké jsou kladené na učitele primární školy. Učitel mateřské školy také pracuje s dětmi sám. ${ }^{3}$ Podrobně se specifiky požadavků na profesní dovednosti učitelů primární školy zabývaly např. Tomková se Spilkovou (2019, s. 13-15) a lze konstatovat, že jsou téměř identické s nároky kladenými na učitele mateřských škol.

V předškolním vzdělávání pracují učitelé s dětmi ve věku, kdy se velmi intenzivně utváří osobnost jedince, děti často v mateřské škole zakouší první sociální a emoční těžkosti, při kterých potřebují účinnou podporu učitele. Aby učitel mateřské školy dostál nárokům tohoto povolání, nemůže se naučit pouze soubor úkonů, které by se daly rutinně zvládat, nebot' v praxi se bude setkávat s jedinečnými př́pady (unique cases) - pedagogickými situacemi,

3 Výjimkou jsou překryvy s ostatními učitelkami/učiteli pracujícími v jedné tř́idě mateřské školy, které se z velké části týkají pobytu venku a doby oběda. Zcela výjimečně pracují učitelky/učitelé společně v době dopoledních či odpoledních činností. 
jejichž řešení bude vyžadovat okamžité tvůrčí rozhodování „v akci“ a bude podléhat systematické reflexi zkušeností. Př́iprava na profesi tak vyžaduje také vytváření základů pro procesy dalšího rozvoje.

To je důvodem, proč se jedním z modelů profesionalizačně orientovaného přípravného vzdělávání učitelů stal model přípravy učitele jako reflektivního praktika (reflective practitioner). Tento koncept vychází z předpokladu, že učitel dokáže teoreticky reflektovat své praktické zkušenosti a že svou praktickou činnost opírá o vědecké poznatky. $V$ české odborné literatuře se můžeme setkat s různými pojetími reflektivního přípravného vzdělávání (např. Janík et al., 2013; Lukášová, 2015b; Píšová et al., 2011; Spilková, 2006, 2019; Syslová et al., 2018a; Švec et al., 2014). Potvrzení vhodnosti této koncepce můžeme najít $v$ Rámcových požadavcích na studijní programy, jejichž absolvováním se získává odborná kvalifikace k výkonu regulovaných povolání pedagogických pracovníků (2017). Autoři této koncepce posílili zejména význam reflektovaných praxí (Stuchlíková \& Janík, 2017, s. 264).

Podrobně se pojetím reflektivně pojatého vzdělávání učitelů mateřských škol na Pedagogické fakultě Masarykovy univerzity zabýváme v trilogii metodických dokumentů (Syslová et al., 2018a, 2018b, 2019) ${ }^{4}$ věnovaných studentům, akademickým pracovníkům a provázejícím učitelům se zaměřením na jeden z nejvýznamnějších prostředků (sebe)reflexe, kterým je portfolio.

\subsection{Portfolio}

Spolu s rozvojem diskuze o proměně přípravného vzdělávání učitelů se objevuje snaha využít portfolio v oblasti hodnocení výstupů pregraduálního vzdělávání (státní závěrečná zkouška) i v oblasti profesního rozvoje a učení studentů. ${ }^{5}$

Portfolio se stalo $\mathrm{v}$ posledních několika dekádách fenoménem, který je zkoumán jak v zahraničním, tak v českém prostředí. Syslová a kol. (2018a, s. 6-10) provedly přehledovou studii, v níž se zaměřily na zahraniční studie z let 2009-2018. Autorky zjistily, že z celkového počtu 345 studií bylo

4 Dostupné z https://munispace.muni.cz/library/catalog/book/1013 (Syslová et al., 2018b); https://munispace.muni.cz/library/catalog/book/1151 (Syslová et al., 2018a); https:// munispace.muni.cz/library/catalog/book/1558 (Syslová et al., 2019).

5 Tomuto tématu bylo věnováno několik kulatých stolů, které otevřelo setkání s tematikou státní závěrečné zkoušky (SZZ) na PdF MU (2017). Další kulaté stoly proběhly na PdF v Liberci (2018) a Českých Budějovicích (2019). 
$35 \%$ věnováno různým aspektům implementace elektronického portfolia. Ukázalo se, že implementace portfolia probíhá na všech stupních vzdělávání, od předškolního po vysokoškolské, a týká se všech jeho aktérů (dětí/žáků, studentů, učitelů i akademických pracovníků). Poměrně silně bylo zastoupeno téma využití portfolia v př́pravném vzdělávání učitelů všech stupňů škol. Výsledky naznačují, že využití portfolia je pro vzdělavatele učitelů velkou výzvou. Autorky v závěru uvádějí, že „základním předpokladem úspěšné implementace portfolia jsou investice ze strany vzdělavatelů učitelů. Tyto investice by měly vycházet z jejich přesvědčení o účelnosti používání portfolia, které dokáží komunikovat studentům, ale také ze znalostí teorie portfolia“ (Syslová et al., 2018a, s. 11).

Výzkumy věnované tématu portfolia $\mathrm{v}$ českém prostředí jsme také podrobily analýze. ${ }^{6}$ Zkoumaly jsme odborné texty z let 2000-2019. V první dekádě jsme měly možnost nalézt pouze dva tituly věnované portfoliu: Studentské portfolio jako zdroj poznání postoje začínajících studentů učitelství (Svatoš, 2006) a Portfolio v profesní př́pravě (Píšová et al., 2007). Začátek druhé dekády byl poznamenán př́pravou kariérního řádu. Vznikly dva metodické materiály: Profesní portfolio učitele (Trunda, 2012) a Metodika pro učitele $k$ př́pravě a vedení dokladového portfolia v kariérním systému (NIDV, 2013). Následující publikace již byly zaměřené výhradně na studenty a využití portfolií k jejich učení a zkoumání portfolia v profesionalizačním procesu (Havlíčková, 2012; Lukášová et al., 2014). Výjimkou je učební text Lukášové (2015a), který je určený pro další vzdělávání učitelů Zlínského kraje. Tři časopisecké studie se věnovaly využití portfolia dítěte v mateřské škole (Hegrová, 2014) a žáků ve škole základní (Princlíková, 2015; Václavík, 2014). Ucelený, analyticky pojatý pohled na portfolio představuje monografie Tomkové (2018), která představovala klíčové východisko naší práce.

V souladu s mnoha dalšími autory vnímáme portfolio jako nástroj profesního růstu studentů a později trvalou součást jejich celoživotního procesu profesního učení. Jde o „V čase se nashromažd'ující inventář portfoliových produktů studenta, jehož průběžné vytváření má význam pro něj samého, ale také pro instituci, která ho na profesi připravuje" (Lukášová et al., 2014, s. 9). Aby portfolio naplnilo tento svůj účel, musí se stát základem jeho tvorby sběr, uvážený výběr a promyšlená reflexe (collecting, selecting, reflecting),

6 Zkoumaly jsme časopisy Komenský, Orbis scholae, Pedagogická orientace, Pedagogika a Studia Paedagogica. 
které zprostředkovávají vhled do studentova profesního růstu. Portfolio by mělo obsahovat dokumenty nasbírané během praxe a doplněné doklady o studiu, výpisky z četby, seminárními pracemi a dalšími materiály dle vlastního uvážení.

V rámci výuky na Pdf MU využíváme obou typů portfolia - jak vývojového (process portfolio), tak prezentačního (product portfolio) (Píšová et al., 2007, s. 42). Cílem je shromáždit a uspořádat vybrané artefakty a dokumenty tak, aby plasticky zachycovaly studentův vývoj a jeho profesní uvažování, což zahrnuje např. i zařazení méně kvalitních prací, na kterých je ale možné s odstupem času ukázat, kam se student/autor ve svém uvažování posunul. Studenti by měli sami dospět k rozhodnutí, podle jakého klíče budou artefakty a dokumenty do portfolia vkládat a jak je budou řadit. Painter (2001, s. 31) dodává, že portfolio umožňuje vytvořit „individualizovaný portrét učitele profesionála reflektujícího svoji filosofii a praxi", vypráví jeho profesionalizační př́běh. Portfolio by mělo zachytit autorovu osobní jedinečnost, jeho schopnosti, osobní zaměření i vnitřní přesvědčení, dokladovat širokou škálu způsobů jeho práce.

Tento aspekt již souvisí spíše s druhým typem portfolia - prezentačním, který má sumativní funkci. Představuje tzv. „výkladní skř́ńn“. Znamená to, že obsahuje dokumenty dokládající vlastní profesní kvality, úspěchy a silné stránky. Ve studijním programu Učitelství pro mateřské školy se stalo portfolio součástí státní závěrečné zkoušky. Aby byly naplněny cíle obou typů portfolií, je nezbytné, aby byl student podporován vyučujícími k hlubšímu porozumění procesu stávání se učitelem, k formulování vlastního pedagogického př́ístupu a také ke zvyšování profesního sebevědomí a odpovědnosti, což mu pomůže při přípravě ke státní závěrečné zkoušce i během ní. Student tak získává novou roli, stává se plnohodnotným spoluaktérem hodnocení portfolia (student ownership; Wyatt \& Looper, 1999, s. 16) neboli se může „naprosto legitimně snažit promyšleně ovlivňovat názory ostatních“ (Paulson \& Paulson, 1996, s. 41).

\subsection{Pojetí výuky v predmětu Tvorba profesního portfolia}

Důležitý činitel reflektivně pojatého přípravného vzdělávání učitelů představují výukové strategie, které vyučující volí. ${ }^{7} \mathrm{~V}$ současné době je preferováno pojetí, které vychází ze sociokonstruktivistických přístupů (podrobněji

7 Na výuce se podílejí především akademičtí pracovníci, ale využívají se také externí pracovníci $\mathrm{z}$ řad zkušených učitelů z praxe či jiných odborníků. 
např. Kasáčová, 2005, s. 23-31; Štech, 1999, s. 191; Vašutová, 2002, s. 56-58), které chápou proces učení ,jako proces objevování, konstruování a rekonstruování poznatků, postojů, dovedností a hodnot na základě vlastní činnosti a dosavadních zkušeností" (Spilková, 2019, s. 282). Takto chápaný proces učení umožňuje rozvíjet kognitivní doménu v součinnosti „sociálních vztahů, osobních dovedností a lidských hodnot" (Vašutová, 2002, s. 72), proto v něm významnou roli hraje kooperativní a vrstevnické učení (Kasíková, 2015b, s. 85-86).

Aktivní zapojení studentů do výuky je považováno za jeden z důležitých faktorů kvalitní vysokoškolské výuky (Kasíková, 2015b, s. 87; Spilková, 2006, s. 22; Vašutová, 2002, s. 192). Pro zvládání takto pojaté pregraduální přípravy učitelů včetně využívání různých reflektivních technik je zapotřebí erudovaných vysokoškolských učitelů, kteří se stávají facilitátory studentova autonomního rozvoje a učení (Vašutová, 2002). Vysokoškolská výuka dnes klade důraz na „konstruující se subjektivitu studenta učitelství, který je považován za hlavního aktéra svého profesního vývoje a (spolu)tvůrce své profesní identity" (Spilková, 2019, s. 283).

Z těchto kořenů vysokoškolské didaktiky vycházela i naše koncepce výuky v kurzu Tvorba profesního portfolia, který probíhá jako volitelný předmět pro studenty programu Učitelství pro mateřské školy $\mathrm{v}$ obou formách studia. Kurz byl otevřen jako jeden z výstupů projektu FRMU ${ }^{8}$. Kurz byl veden jako bloková výuka a obsahoval čtyřri čtyřhodinové semináře.

Východiskem práce v kurzu se stalo zjištění, s jakými představami a očekáváními studentky přicházejí. Následná diskuze vytvořila živnou půdu pro teoretické ukotvení fenoménu portfolia, které jsme dále rozvíjely v praktických aktivitách. Významný podíl při výuce hrálo samostudium - každý blok zahrnoval domácí úkol, který tvořil východisko pro další setkání. Online prostor v podobě moodlinky umožňoval vkládat vypracované úkoly a poskytovat vzájemnou zpětnou vazbu.

Naším cílem bylo umožnit studentkám proniknout hlouběji do problematiky strukturování portfolia, navazovat na vlastní zkušenosti, hledat cestu dalšího rozvoje, a tak proměňovat jejich profesní zkušenost. Portfolio se mělo stát živoucím vyjádřením jejich postoje $\mathrm{k}$ profesi a zároveň zprostředkovatelem vhledu do jejich profesního růstu.

8 MUNI/FR/0872/2017; členy řešitelského týmu vedle autorek článku byly M. Píšová a A. Tomková. 
Jádro kurzu tvořila společná diskuze: studentky přemýšlely o smyslu, účelu a možnostech portfolia $v$ rámci vysokoškolského studia i své další profesní dráhy. Pracovaly ve dvojicích, využívaly kooperativní činnosti zaměřené na sdílení a vzájemnou inspiraci v oblasti kritérií kvality i obsahu a struktury portfolia. K dalším strategiím patřilo vzájemné kolegiální hodnocení a individuální aktivizující činnosti inspirované postupy kritického myšlení směřující k hlubokému zamyšlení nad vlastním pojetím portfolia jako obrazu autorské profesní individuality. Byly uplatněny také reflektivní praktiky, což umožnilo identifikovat a formulovat počáteční očekávání i celkový přínos kurzu pro každou účastnici.

\section{Metodologie}

Širším záměrem tohoto textu je přispět k diskurzu o proměnách a kvalitě vysokoškolského vzdělávání prostřednictvím akčního výzkumu. Akční výzkum hledá cesty jak optimálně přenést zjištění získaná výzkumem do praxe a urychlit proces případných změn. Významným předpokladem je teze, že „vliv výzkumu se zvětší, pokud se na něm budou aktivně podílet ti, jichž se týká" (Hendl, 2005, s. 138). Tento předpoklad staví na zásadě, že výzkumníci i zkoumaní (vyučující a studenti) mají rovnocenné postavení, témata zkoumání jsou vztažena k praxi a proces výzkumu je procesem změny. Kaliszewska (2013, s. 587-596) upozorňuje na skutečnost, že pojem akční výzkum (action research) v současnosti doznává vnitřní obsahové divergence vlivem množství a různorodosti studií, které se k němu hlásí.

Nezvalová s oporou v zahraničních autorech charakterizuje akční výzkum jako formu sebereflexe pedagogické situace, která ovlivňuje kvalitu pedagogické praxe (Kemmis, 1983, in Nezvalová, 2003, s. 300). Upozorňuje na vztah nevědomé a vědomé činnosti (McNiff, 1988, in Nezvalová, 2003, s. 300), kdy účastníci podrobují svá nevědomá a intuitivní rozhodnutí analýze, shromažd'ují informace, kladou otázky, sdílejí názory a vyhodnocují výsledky. Tento proces probíhá v určitém ohraničeném cyklu. Tato cyklická spirála (Kaliszewska, 2013, s. 593) vzniká přirozeně a odpovídá dynamice hermeneutického kruhu porozumění ${ }^{9}$, tj. probíhá od předběžných představ (předsudků) přes př́mou hermeneutickou zkušenost v podobě konfrontace s realitou k novým, revidovaným (lepším) představám, s nimiž můžeme znovu vstoupit do kruhu porozumění. Cyklus probíhá v určitému časovému období, v našem př́padě odpovídá délce akademického semestru.

9 Označení hermeneutický kruh představuje lingvistický koncept, jde o model porozumění a výkladu textu (v nejširším slova smyslu), jehož součástí je ověřování, což vede ke změně porozumění na straně čtenáře. 
Podstatou akčního výzkumu jako způsobu zachycování proměn ve výuce (Kasíková, 2015b, s. 84) je proces syntetizace vlastního činění, jež vede k hlubšímu porozumění, a tak ovlivňuje další rozhodnutí. Naše výuka byla založena na aktivitě studentů: konkrétní tvořivé práci na vlastním portfoliu a paralelním sdílení nápadů, postřehů a hodnocení, což doprovázely otázky (Co dělám? Co to znamená? Jak to dělám? Jak to mohu dělat jinak? Co se učím? Co je důležité? Co budu dělat dále?), které měly posilovat a rozvíjet metakognitivní myšlenkové procesy a posouvat studentské chápání role portfolia od heteronomního k autonomnímu př́stupu.

\subsection{Cíle výzkumu a výzkumné otázky}

Cílem zkoumání bylo zachytit a popsat, jak ovlivňují výukové strategie (kooperativní a vrstevnické učení) proces profesionalizační individualizace studentek. Zavedené strategie jsme oveřrovaly a následně posuzovaly dosažené výsledky, tj. šlo o typ pro-aktivního akčního výzkumu (Schmuck, 1997, in Nezvalová, 2003, s. 301). Základní kámen celého procesu představovaly výzkumné otázky, které vymezily teoretický rámec, ovlivnily volbu metod a tvořily průsečík cíle výzkumu a spolehlivosti šetření (Hendl, 2005, s. 146; Švaříček et al., 2007, s. 62). Hlavní výzkumná otázka zněla: Jak absolvování předmětu Tvorba profesního portfolia ovlivňuje profesionalizační rozvoj (profesní identitu) studentek? Specifické otázky se zaměřovaly na jednotlivé aspekty profesionalizace: (1) Jakou úroveň myšlení vykazují studentky na konci kurzu? (2) Jaké př́běhy individuální profesionalizace zachycují portfolia studentek? (3) Jak studentky vnímají portfolio v kontextu svého profesionalizačního rozvoje?

\subsection{Sběr dat a jejich analýza}

Výzkumný vzorek tvořilo 17 studentek $^{10} \mathrm{z}$ prezenční i kombinované formy studijního oboru Učitelství pro mateřské školy. Naším záměrem bylo sledovat rozvoj profesní identity, proto se naše pozornost zaměřila především na ty studentky, které v jarním semestru 2020 ukončily studium státní závěrečnou zkouškou, při které portfolio uplatnily, což nám umožnilo sledovat a zaznamenat celý proces této etapy profesionalizace.

Výzkumnými metodami se stala analýza dokumentů, rozhovor, ohnisková skupina a zúčastněné pozorování. Předmětem analýzy byly dokumenty v podobě finálních portfolií, vzájemného studentského písemného hodnocení portfolií, písemného výstupu z úvodní aktivity Vím - Chci vědět - Dozvěděl

10 V souladu s etickým požadavkem důvěrnosti byla jména studentek změněna. 
jsem se $(\mathrm{V}-\mathrm{Ch}-\mathrm{D})^{11}$, záznamu ohniskové skupiny při závěrečném hodnocení kurzu, terénních zápisků zaměřených na roli portfolia v průběhu státní závěrečné zkoušky a záznamu polostrukturovaného rozhovoru, který jsme vedly po jejím skončení. Podstatný moment zde představoval požadavek triangulace, pravidlo tří pevných bodů ${ }^{12}$, které umožňuje „na základě dvou známých bodů a úhlů trojúhelníku určit bod třetí, neznámý" (Hendl 2005, s. 149-150; Švaříček et al., 2007, s. 202). Tabulka 1 ukazuje způsob mnohonásobné triangulace zdroje dat (finální portfolia, písemné dokumenty a audio nahrávky), zdroje metod (analýza dokumentů, rozhovor a pozorování) s nasazením dvou výzkumníků (Hendl, 2005, s. 149-150).

\section{Tabulka 1}

\section{Způsob triangulace}

\begin{tabular}{|c|c|c|}
\hline \multicolumn{3}{|c|}{$\begin{array}{l}\text { Hlavní výzkumná otázka: } \\
\text { Jak absolvování předmětu Tvorba profesního portfolia ovlivňuje profesionalizační rozvoj } \\
\text { studentek? }\end{array}$} \\
\hline Výzkumná metoda & Předmět analýzy & Specifická výzkumná otázka \\
\hline $\begin{array}{l}\text { ohniskový rozhovor } \\
\text { analýza dokumentů }\end{array}$ & $\begin{array}{l}\text { audio záznam rozhovoru se } \\
\text { studenty na konci kurzu } \\
\text { písemné hodnocení portfolia } \\
\text { písemný výstup z aktivity V-Ch-D }\end{array}$ & $\begin{array}{l}\text { Jakou úroveň myšlení } \\
\text { vykazují studentky na konci } \\
\text { kurzu? }\end{array}$ \\
\hline analýza dokumentů & portfolio & $\begin{array}{l}\text { Jaké př́běhy individuální } \\
\text { profesionalizace zachycují } \\
\text { portfolia studentek? }\end{array}$ \\
\hline $\begin{array}{l}\text { zúčastněné pozorování } \\
\text { polostrukturovaný rozhovor }\end{array}$ & $\begin{array}{l}\text { terénní poznámky průběhu SZZ } \\
\text { audio záznam rozhovoru se } \\
\text { studenty a zkoušejícími po SZZ }\end{array}$ & $\begin{array}{l}\text { Jak studentky vnímají } \\
\text { portfolio v kontextu svého } \\
\text { profesionalizačního rozvoje? }\end{array}$ \\
\hline
\end{tabular}

Jako klíč pro zodpovězení hlavní výzkumné otázky nám posloužily fáze pojetí výuky formulované Spilkovou a kol. (2004, s. 147) a dále rozpracované Lukášovou a kol. (2014, s. 14).

11 Šlo o strategii kritického myšlení, variantu metody I.N.S.E.R.T., která nám sloužila k posouzení východisek práce, $\mathrm{k}$ následné rekapitulaci procesů práce, ke zhodnocení a uvědomění si významu a možností portfolia jako součásti vlastní profesní cesty (srov. Grecmanová et al., 2000, s. 77; Spilková, 2005, s. 126).

12 Třeštík (1997, s. 13-14) upozorňuje na okolnost pravidla tří pevných bodů, které představují záruku pohybu horolezce po kolmé stěně. Pokud by však chtěl být jištěn čtyřmi pevnými body, „nehnul by se z místa“. Právě ony tři jistoty umožňují hledat další možnosti posunu vpřed, další pevný bod, i za cenu jisté (dočasné) vratkosti pozice. 


\section{Tabulka 2}

Kategoriální systém vývoje profesní identity

\begin{tabular}{|c|c|}
\hline Kategorie & Obsahové vymezení \\
\hline $\begin{array}{l}\text { Startovací identita } \\
\text { (předběžné pojetí } \\
\text { výuky) }\end{array}$ & $\begin{array}{l}\text { Spontánní, živelné a intuitivně vzniklé názory; postoje na základě } \\
\text { vlastních prožitků z dětství a subjektivních zkušeností v roli žáka/ } \\
\text { studenta. Významnou roli hraje emocionální složka (pozitivní a } \\
\text { negativní prožitky), která způsobuje relativní zakotvenost prekoncepcí } \\
\text { a určitou rezistenci vůči změně. }\end{array}$ \\
\hline $\begin{array}{l}\text { Proměňovaná } \\
\text { identita } \\
\text { (krystalizující pojetí } \\
\text { výuky) }\end{array}$ & $\begin{array}{l}\text { Základy vlastního pojetí výuky, které vzniká ve styku se školní } \\
\text { realitou, s prvními zkušenostmi v roli učitele a ve styku s teoretickými } \\
\text { pedagogicko-psychologickými poznatky. Postupně se stabilizuje, } \\
\text { ve velké míře zůstává implicitní, intuitivní a relativně neuvědomované. }\end{array}$ \\
\hline $\begin{array}{l}\text { Profesní identita } \\
\text { (explicitní pojetí } \\
\text { výuky) }\end{array}$ & $\begin{array}{l}\text { Zvědomování, racionalizace a verbalizace implicitních, intuitivních } \\
\text { poznatků, založené na kritickém prozkoumávání „zamlčených“ } \\
\text { předpokladů vlastního jednání, přístupů a rozhodování. Podstatou je } \\
\text { verbalizace, nutnost slovně formulovat, pojmenovávat, vysvětlovat } \\
\text { a argumentovat. }\end{array}$ \\
\hline
\end{tabular}

K detekování nuancí v myšlení studentek, což byla oblast, na kterou se zaměřovala první specifická otázka, jsme využily kategoriální systém podle Píšové (2005, s. 145). Kategorie vycházejí z myšlenkových operací Bloomovy taxonomie kognitivních cílů (Bloom, 1956) a umožňují třídit myšlenkovou úroveň písemných i mluvených projevů studentek (tabulka 3). Pro zajištění přiměřené míry objektivity (resp. reliability) byl kategoriální systém ověřován oběma výzkumnicemi na $10 \%$ výzkumného vzorku, zde jsme dosáhly přímé shody v $86 \%$. Všechny záznamy slovních projevů studentek byly analyzovány v programu ATLAS.ti.

Pro analýzu portfolia jsme se opíraly o kriteriální systém kvality navržený Tomkovou (2018, s. 212). Aby portfolio naplnilo svůj účel, tzn. podporovalo rozvoj profesní identity, mělo by (1) být jasně strukturováno, (2) obsahovat autentické dokumenty/artefakty, které vyjadřují, co je pro studenta důležité, (3) obsahovat reflektivní poznámky týkající se jak teorie, tak praktických zkušeností studenta, (4) obsahovat výzvy, podněty pro zlepšování kvality profesních dovedností studenta.

Při vlastní analýze jsme se pohybovaly v mantinelech emancipace, tj. hledání vlastních norem kritérií, a adaptace, tj. dodržování vnějších stanovených kritérií (Kaliszewska, 2013, s. 595). Sebraná data jsme zkoumaly prizmatem vnějších (objektivních) standardů (viz tabulka 2 a kritéria podle Tomkové, 
2018, s. 212) a zároveň s ohledem na zachycení jedinečnosti a individuálního charakteru profesního rozvoje studentek.

\section{Výsledky}

Výsledky prezentovaného výzkumu předkládáme (1) z pohledu procesů profesního rozvoje studentek odrážejících jejich profesní myšlení, což je dáno první výzkumnou otázkou, (2) z hlediska individuálních profesionalizačních příběhů jednotlivých studentek, a poté nahlížíme (3) na získaná data z hlediska třetí výzkumné otázky, tedy z hlediska vnímání portfolia.

\subsection{Profesní myšlení studentek}

Nyní se zaměříme na způsob uvažování studentek programu Učitelství pro mateřské školy z hlediska úrovně myšlenkových operací (srov. Syslová, 2017, s. 176). Tabulka 3 obsahuje popis jednotlivých úrovní myšlení doložený příklady z písemného projevu studentek.

\section{Tabulka 3}

Kategoriální systém myšlenkových operací sebereflexe učitelek

\begin{tabular}{|c|c|c|}
\hline Kategorie & Obsahové vymezení výroků & Příklady výroků studentek \\
\hline Popis & Výčet, popis faktů. & $\begin{array}{l}\text { Nejprve se autorka představuje, vyzdvihuje } \\
\text { své vzdělání a praxi. Seznamuje nás } \\
\text { s mateřskou školou, ve které děti } \\
\text { pedagogicky vzdělává. }\end{array}$ \\
\hline Analýza & $\begin{array}{l}\text { Úvahy o tom, jak a proč } \\
\text { je portfolio uspořádáno/ } \\
\text { strukturováno, s jakým cílem } \\
\text { byly vybírány artefakty apod. }\end{array}$ & $\begin{array}{l}\text { Cíle jsou v portfoliu zařazeny na konci } \\
\text { a vystihují směr, kterým se autorka bude } \\
\text { dále profilovat. }\end{array}$ \\
\hline Hodnocení & $\begin{array}{l}\text { Osobní hodnoticí soud } \\
\text { vyjadřující uprímný názor } \\
\text { na portfolio, opírá se } \\
\text { o teoretické pojmy a koncepty. }\end{array}$ & $\begin{array}{l}\text { Oceňuji materiály a praktické ukázky. } \\
\text { Také mne zaujal velmi detailní popis praxe } \\
\text { se zaznamenanými rozhovory dětí. }\end{array}$ \\
\hline $\begin{array}{l}\text { Návrh } \\
\text { alternativních } \\
\text { postupů }\end{array}$ & $\begin{array}{l}\text { Návrh efektivnějších, prrípadně } \\
\text { alternativních řešení, opírá } \\
\text { se o teoretické znalosti } \\
\text { i praktické zkušenosti. }\end{array}$ & $\begin{array}{l}\text { K materiálüm ohledně komunikace bych } \\
\text { doporučila zpracovat reflexi, aby autorka } \\
\text { sama pro sebe zhodnotila, zda teorii využívá } \\
\text { v praxi a jakým způsobem. }\end{array}$ \\
\hline Generalizace & $\begin{array}{l}\text { Výroky konfrontující vlastní } \\
\text { názory s teorií, schopnost } \\
\text { formulovat obecnější } \\
\text { principy s využitím odborné } \\
\text { terminologie. }\end{array}$ & $\begin{array}{l}\text { Autorku charakterizuji jako začínající } \\
\text { učitelku, která pracuje na svých profesních } \\
\text { kompetencích dalším vzděláváním, } \\
\text { zároveň má jasnou vizi a chce jít cestou } \\
\text { připraveného, empatického a zároveř } \\
\text { respektujícího učitele. }\end{array}$ \\
\hline
\end{tabular}




\begin{tabular}{|c|c|c|}
\hline Kategorie & Obsahové vymezení výroků & Příklady výroků studentek \\
\hline Metakognice & $\begin{array}{l}\text { Výroky spojené s přemýšlením } \\
\text { o sobě a vlastních profesních } \\
\text { dovednostech. }\end{array}$ & $\begin{array}{l}\text { Mluvím spíše ze své zkušenosti, protože } \\
\text { někdy lituju, že jsem si nedala více práce } \\
\text { s rozepsáním takovýchto myšlenek, protože } \\
\text { to tenkrát bylo všechno přece jasné, } \\
\text { ale za pár let si už nemúžu na detaily } \\
\text { rozpomenout. }\end{array}$ \\
\hline Jiné & $\begin{array}{l}\text { Výroky, které nespadají do } \\
\text { žádné z výše uvedených } \\
\text { kategorií. Zpravidla jde o } \\
\text { nepodložené soudy a závěry. }\end{array}$ & $\begin{array}{l}\text { Z jejího životopisu jsem přečetla, že je ročník } \\
97 \text { a narodila se v Břeclavi. Z čehož mǔžeme } \\
\text { usuzovat pravý jihomoravský temperament. }\end{array}$ \\
\hline
\end{tabular}

Materiál pro analýzu myšlenkových operací pocházel ze dvou zdrojů dat a měl písemnou formu. První zdroj vznikl na úvodním semináři. Každá studentka dostala list papíru stejné velikosti, který přeložením rozdělila na tři stejné díly. Do prvního oddílu formulovala odpověd' na otázku Co o portfoliu vím? a do druhého Co se chci dovědět? Třetí díl papíru s otázkou Co jsem se dověděla? měly studentky vyplnit na konci kurzu.

Odpovědi na první otázku nám pomohly zacílit kurz směrem k očekávání účastnic. Vyplynulo, že studentky mají o portfoliu poměrně jasnou představu opírající se o četbu odborné literatury: není to pouhý „zásobník“; má sloužit k seberozvoji a sebereflexi; je součástí SZZ; profesní portfolio je strukturované, promyšlené a výběrové a slouží k profesní prezentaci autora.

Odpovědi na druhou otázku ukázaly, že studentky zatím setrvávaly v heteronomní rovině myšlení1 ${ }^{13}$ o portfoliu, tj. byly vedeny vnějším účelem: jak ho správně sestavit; jak ho správně pojmout; jak má správně vypadat; jak obsáhlé by mělo být; jaké seminární práce do něj mám vkládat; jak ho prezentovat u SZZ; jak s ním pracovat. Naším cílem bylo vyvést je z pasivní pozice, ukázat jim, že mohou převzít aktivitu, že je nutné přijmout odpovědnost za výslednou podobu svého portfolia a že mohou k jeho tvorbě přistupovat tvořivě a originálně.

Zde se opíráme o koncept heteronomie a autonomie myšlení formulovaný Piagetem a Inhelderovou (2007, s. 110-111), kdy v prvním případě chování (dítěte) závisí na vnější kontrole, na odměně či trestu, na nátlaku vnějšího okolí (dospělých), druhý typ se projevuje nezávislostí a převzetím zodpovědnosti za sebe a svá rozhodnutí. 
Další odpovědi ukázaly, že účastnice kurzu počítají s možností inspirovat se při tvorbě portfolia navzájem, což představovalo nosný bod pro naše záměry. Odpovědi na třetí otázku (V-Ch-D) zpracováváme v kapitole 3.3.

Druhým zdrojem vhledu do způsobu myšlení studentek byla vzájemná písemná hodnocení portfolií. Výroky jsme kódovaly podle stanovených kategorií myšlenkových operací (tabulka 3). Jak ukazuje tabulka 4, všech sedmnáct studentek ve svém písemném projevu využilo analýzu a hodnocení. Patnáct uplatnilo popis a návrh alternativních postupů. $V$ jednom př́padě se objevily metakognitivní výroky v podobě úvah o sobě a vlastních profesních dovednostech. Šest hodnocení obsahovalo obecnější generalizace a závěry, formulované s pomocí odborných termínů. $\mathrm{V}$ kategorii Jiné se sešly výroky, které nespadaly do jiných kategorií. Většinou se jednalo o tvrzení, která se nezakládala na prokazatelných faktech. Šlo o subjektivní interpretace, jež často obsahovaly zkreslení, a tvořily tak protiklad popisu.

\section{Tabulka 4}

Kategoriální systém myšlenkových operací sebereflexe učitelek - myšlenkové operace využité studentkami

\begin{tabular}{|c|c|c|c|c|c|c|c|}
\hline $\begin{array}{l}\text { Jména } \\
\text { studentek }\end{array}$ & Popis & Analýza & Hodnocení & Alternativy & Generalizace & Metakognice & Jiné \\
\hline Alžběta & $\mathrm{x}$ & $\mathrm{x}$ & $\mathrm{x}$ & $\mathrm{x}$ & & & $\mathrm{x}$ \\
\hline Barbora & $\mathrm{x}$ & $\mathrm{x}$ & $\mathrm{x}$ & $\mathrm{x}$ & & & \\
\hline Cecílie & $\mathrm{x}$ & $\mathrm{x}$ & $\mathrm{x}$ & $\mathrm{x}$ & $\mathrm{x}$ & & \\
\hline Daniela & & $\mathrm{x}$ & $\mathrm{x}$ & & & & \\
\hline Eva & $\mathrm{x}$ & $\mathrm{x}$ & $\mathrm{x}$ & $\mathrm{x}$ & & & $\mathrm{x}$ \\
\hline Františka & $\mathrm{x}$ & $\mathrm{x}$ & $\mathrm{x}$ & $\mathrm{x}$ & $\mathrm{x}$ & & $\mathrm{x}$ \\
\hline Gabriela & $\mathrm{x}$ & $\mathrm{x}$ & $\mathrm{x}$ & & & & \\
\hline Hana & $\mathrm{x}$ & $\mathrm{x}$ & $\mathrm{x}$ & $\mathrm{x}$ & $\mathrm{x}$ & & $\mathrm{x}$ \\
\hline Ilona & $\mathrm{x}$ & $\mathrm{x}$ & $\mathrm{x}$ & $\mathrm{x}$ & & & $\mathrm{x}$ \\
\hline Jana & $\mathrm{x}$ & $\mathrm{x}$ & $\mathrm{x}$ & $\mathrm{x}$ & & & $\mathrm{x}$ \\
\hline Klára & $\mathrm{x}$ & $\mathrm{x}$ & $\mathrm{x}$ & $\mathrm{x}$ & $\mathrm{x}$ & $\mathrm{x}$ & $\mathrm{x}$ \\
\hline Lenka & $\mathrm{x}$ & $\mathrm{x}$ & $\mathrm{x}$ & $\mathrm{x}$ & & & $\mathrm{x}$ \\
\hline Monika & $\mathrm{x}$ & $\mathrm{x}$ & $\mathrm{x}$ & $\mathrm{x}$ & & & $\mathrm{x}$ \\
\hline Nad'a & & $\mathrm{x}$ & $\mathrm{x}$ & $\mathrm{x}$ & $\mathrm{x}$ & & $\mathrm{x}$ \\
\hline Olga & $\mathrm{x}$ & $\mathrm{x}$ & $\mathrm{x}$ & $\mathrm{x}$ & & & \\
\hline Petra & $\mathrm{x}$ & $\mathrm{x}$ & $\mathrm{x}$ & $\mathrm{x}$ & $\mathrm{x}$ & & $\mathrm{x}$ \\
\hline Radka & $\mathrm{x}$ & $\mathrm{x}$ & $\mathrm{x}$ & $\mathrm{x}$ & & & $\mathrm{x}$ \\
\hline
\end{tabular}


Většina hodnocení byla vypracována v rozsahu 300-500 slov. Dvě nejkratší obsahovala 57 a 80 slov a šlo o reciproční hodnocení. Malý rozsah, který působil mezi ostatními pracemi nápadně, vyvolával dojem zběžné práce a také určité bezradnosti. Vnucovala se otázka, nakolik šlo o náhodu, že se k sobě dostaly dvě hodnotitelky, které úkol pojaly tímto způsobem. Skutečnost, že ani jedna z této dvojice neuplatnila popis, považujeme za významnou. Obě autorky začaly hodnocením a rovnou navázaly analýzou. Skutečnost, že v těchto dvou př́padech chybí popis, nás upozornila na význam schopnosti ovládat a používat popisný jazyk, který pro nás představuje základ vyšších myšlenkových operací.

Většina hodnocení byla psána nestrukturovaně, ve dvou případech měly autorky potřebu písemné hodnocení rozčlenit na oblasti, které samostatně vytvořily: struktura portfolia, naplnění formálních požadavků, kvalita obsahu portfolia, kvalita prezentace portfolia, doporučení, struktura, filosofie, grafická stránka, závěr, což přispělo k přehlednosti i zacílení hodnocení a svědčilo jak o pečlivém přístupu k úkolu vzájemného hodnocení, tak o potřebě strukturovat své myšlenky, rozčlenit text do jednotlivých oblastí a k těm se podrobněji vyjádřit.

Studentky psaly hodnocení většinou ve třetí osobě: „Františka za tři roky studia posunula své názory o práci učitele docela výrazným krokem." Některé zvolily důvěrnější tón tím, že psaly v první osobě: „Nalezla jsem také ukázky prací z více okruhů, at' už výtvarných (tato práce se mi moc líbila, je na ní vidět autorčina kreativita, ještě více by se mi v práci líbilo, kdyby byly fotografie barevné), hudebních atd...

Originální přístup zvolily autorky dvou nejrozsáhlejších hodnocení. Obě v textu autorku portfolia př́mo oslovovaly, čímž vytvořily atmosféru založenou na otevřeném sdílení nápadů a myšlenek: „Složka nazvaná vývojová má velký potenciál právě pro tebe samotnou. Pomůže ti se ohlédnout zpátky v čase, v tvých pocitech i pohledu na svět, a vidět tak svůj vlastní posun v profesní dráze." Opačný pól zastupovala hodnocení, kde přetrvávaly stopy heteronomního přístupu k tvorbě portfolia. Hodnotitelky mluvily o majitelce portfolia ve třetí osobě, jako by hodnocení nebylo určeno jí, ale nějaké třetí, nadřazené autoritě:

Vypadá to, že Petra s portfoliem pracuje a vkládá si do něj stále nové artefakty. Není v něm ovšem viditelné ohlédnutí se a zastavení u již vytvořených artefaktů. 
Možná to Petra dělá a jenom si nezapisuje nové poznámky. [...] Tudíž by to u lidí, kterým se dostane portfolio do ruky, mohlo vyvolat pocit, že se s portfoliem průběžně nepracuje.

Lze konstatovat, že hodnocení byla autorkami přijata a představovala významný milník na cestě k hledání finální podoby vlastního portfolia.

Studentky se s pozicí hodnotitele vypořádávaly různě, volily rozličné strategie a prostředky. Nejčastěji šly cestou pozitivní charakteristiky, povzbuzení a motivující pochvaly. Kladné hodnocení se někdy stalo odrazovým můstkem ke kritickým postřehům, které měly podobu osobních dojmů i věcných rad (například upozornění na pravopisné chyby). Touha proniknout do struktury portfolia, pochopit ho a poskytnout majitelce kvalitní zpětnou vazbu však někdy vyústily v nepodložené domněnky: „Portfolio má světle modrou barvu, z čehož lze usuzovat, že podle barvy je Radka klidný člověk, který si potrpí na uspořádání." Silný dojem vyvolalo metaforické vyjádření:

Toto portfolio bych přirovnala k poupěti. Vypadá to, že z něj vyroste kvítek, bylo by ale třeba ho ještě něčím zalít, aby plně vykvetlo. V̌řím, že pokud bude toto portfoliové poupě zalévat, tak nejen, že vykvete, ale také začne krásně vonět a jistě naláká včelky, které tu vůni ocení.

Metafora představuje způsob vyjádření, jež pracuje s originálními příměry a obrazy. Dotýká se mysli i citů čtenáře. Tím, že studentka sáhla k obraznému vyjádření, zvolila prostředek, který jí dovolil přiblížit se čtenáři, mezi hodnotitelem a hodnoceným nastolit důvěru jako předpoklad vzájemné otevřenosti a podpory, které pro nás představují naplnění smyslu vzájemného hodnocení.

\subsection{Individuální profesionalizační př́běhy studentek}

Individuální př́běhy procesu profesionalizace jsme formulovaly na základě analýzy portfolií a analýzy rozhovorů se čtyřmi studentkami, které v prímé návaznosti na kurz absolvovaly v květnu 2020 SZZ.

\section{Barbora jako autorka studijně-profesního portfolia}

Portfolio má 81 stran. Barbora na začátek zařadila vzdělávací certifikáty, které naznačují zaměření na oblast montessori pedagogiky a také na oblast vzdělávání dětí do tř́ let věku. Z životopisu se dovídáme, že Barbora vystudovala gymnázium, dosáhla inženýrského titulu a pracovala jako účetní, po pěti 
letech této praxe se rozhodla pro studium učitelství pro mateřské školy kombinovanou formou.

Strukturu svého portfolia Barbora podřídila tematickým okruhům SZZ. Po stranách vložila barevné záložky a podle nich dokumenty rozčlenila do šesti tematických oblastí: Charakteristika dítěte, Pedagogicko-psychologická diagnostika, Způsob učení dětí prèedškolního věku, Projektování, Diferenciace vzdělávání, Interakce v MŠ. Horní okraj dokumentu opatřila dalšími barevnými záložkami s čísly státnicových okruhů z pedagogiky a psychologie, na některých vidíme více čísel současně. To umožňuje rychlou orientaci v dokumentech a ukazuje autorčin záměr využít portfolio během SZZ. Barbora vysvětluje, jak postupovala: „A pomocí těch štítků jsem si označila, ke které otázce by to mohlo být. No, potom jsem si vzala ten papír s otázkama a (...) dohledávala, co bych si tak mohla k tomu materiálu ještě přidat, abych to portfolio měla co nejvíc výstižné k těm otázkám."

V praktické přípravě získávala Barbora po celou dobu studia dobré hodnocení. Na první praxi provázející učitelka oceňuje zájem studentky o chod mateřské školy, její dobrý vztah k dětem i fakt, že si sjednala další praxi nad rámec svých studijních povinností. Celkový dojem dokresluje nedatovaný pracovní list s názvem Jak porozumět školním interakcím zařazený v závěru portfolia, kde se Barbora označuje jako „upřímná, k dětem kamarádská“ a pojmenovává i své slabiny: „Omlouvám chování dětí, nerada ř́kám nepř́ijemné věci rodičům."

Většina materiálů není opatřena reflektivními poznámkami ani není nijak komentována, jako by Barbora neměla zvláštní potřebu sama o sobě a svých pedagogických dovednostech přemýšlet. Výjimku tvoří komentář na s. 36, kde jsou ve formuláři tematického plánu ručně psané poznámky, které se týkají způsobu formulace výukových cílů a způsobu záznamu plánovaných činností s dětmi. Není však jasné, zda se jedná o Barbořiny myšlenky či jde o zachycení komentáře vyučujícího: „Musím si udělat kompetence a cíle + očekávání + výstupy. Musí na sebe navazovat. Nerozdělovat děti podle věku, ale podle individuálních dovedností." Studentka přiznává, že příprava činností pro heterogenní třídu je pro ni obtížná, ale postupně se zlepšuje. Uvědomuje si, že „materiály k činnostem“ by neměla připravovat ona, ale měly by to dělat „děti samy“. Oblasti, ve kterých se chce zlepšit, vyjadřuje slovy: „kooperace, spontaneita, samostatnost“. Kritický pohled sama na sebe doplňuje hodnocení učitelky: „Nikoho neprotežuje, bude z ní výborná učitelka." Vlastnímu 
pedagogickému výkonu věnuje pozornost výjimečně: „Zvládám chování dětí, ale nejsem spokojená se svou důsledností (...) někdy si nejsem jistá, jak přesně zasáhnout, teprve hledám nejlepší cesty," píše v pátém, předposledním semestru studia.

Barbořiny záznamy a komentáře jsou primárně zaměřeny na děti, jejich projevy a chování. Velký prostor věnovala diagnostice. Do portfolia zařadila seminární práce na téma školní zralosti či plán pedagogické podpory dítěte, které se ocitlo v těžké životní situaci.

Na začátek portfolia Barbora zařadila dvě fotografie - momentky ze školky, kde v roce 2019, na konci studia, pracovala jako učitelka. Vidíme skupinu dětí a dospělých, jak jdou po cestě mezi ovocnými stromy, usmívají se a zvedají ruce, jako by někoho vítali či chtěli obejmout. Druhá fotografie zachycuje skupinu učitelek a dětí v maškarních kostýmech. Podle Barbory fotografie zachycují klima a vztahy mateřské školy, kde působí, což pro ni má „velkou důležitost", jelikož dobré vztahy na pracovišti vnímá jako zásadní podmínku „pro kvalitní práci“ s dětmi, kdy jako učitelé „ovlivňujeme jejich budoucnost“. Zdá se, že Barbořino rozhodnutí stát se učitelkou bylo učiněno po zralé úvaze a je myšleno vážně.

Podle kritérií Tomkové (2018, s. 195) lze portfolio označit jako studijně-profesní, Barbora jej tvořila především ,jako podporu své proaktivní přípravy na státnice“. Je zřetelný pečlivý př́stup k obsahu i složení portfolia, které má demonstrovat autorčinu profesní připravenost, k výrazným rysům patří členění z hlediska dítěte, což lze chápat jako projev partnerského přístupu k dětem, celkový výraz jejího učitelského pojetí.

\section{Lenka jako autorka procesně-bilančního portfolia}

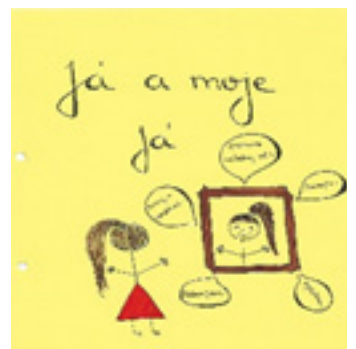

Portfolio je tvořeno 122 listy. Dokumenty jsou tematicky roztříděny do čtyř různě obsáhlých částí, které studentka nazvala Já a moje já (certifikáty, osvědčení a formuláře hodnocení a sebehodnocení, včetně hodnocení spolužaček), Respektovat a být respektován (zde se zaměřuje na dítě, způsoby komunikace, diagnostiku a speciální vzdělávací potřeby), Hudba smysl mého života (metodické materiály a didaktické seminární práce z hudební, literární a tělesné výchovy) a Rozvoj osobnosti (tematické plány z mateřské 
školy, kde v současné době působí jako učitelka). Lenka své pojetí portfolia objasňuje slovy: Kniha. Moje kniha plná vědomostí, zkušeností a představ.

Lenka vystudovala gymnázium a bakalářské studium s ekonomickým zaměřením. Pro učitelství mateřské školy se rozhodla až později, bez předchozí pedagogické zkušenosti. Nyní, na konci prezenční formy studia, pracuje (na částečný úvazek) jako učitelka v mateřské škole. Lenka se celoživotně zajímá o hudbu - hraje na klavír, na flétnu a na klarinet - což rezonuje s mentální mapou v poslední části portfolia nazvanou Čeho chci dosáhnout v nejbližší době. Jejím snem je učit hře na flétnu.

Z dokumentů portfolia vyplývá, že Lenka trpěla na začátku studia ostychem a těžko navazovala s dětmi kontakt. Významně ji ovlivnila kniha Respektovat a být respektován, pomohla jí zdokonalit způsob komunikace $s$ dětmi. Reflektivní poznámky ukazují Lenčinu trvalou snahu přistupovat k dětem s respektem, zkoušet zásady efektivní komunikace v praxi: „Po přečtení knihy jsem začala komunikovat s dětmi úplně jinak. Dokážu pracovat s hlasem, volím popisnou formu výkladu či pochval. Udržuji s dětmi oční kontakt i komfortní zónu." Lenčin posun v této oblasti dokládá záznam v pedagogickém deníku ze druhého roku studia. Zde již není po ostychu stopy, Lenka s plačícím dítětem hovoří s rozvahou a respektem, její argumenty jsou přesvědčivé:

„To není nic špatného, když jde pro tebe tatínek, i pro mě chodil někdy do školky tatínek, když maminka nemohla. Maminka musí ležet, aby se uzdravila, to přece taky sama znáš. Když jsi nemocná, tak ti paní doktorka řekne, abys odpočívala." Vita se na mě usmála, šly jsme spolu k výtvarnému stolku, kde jsme každá nakreslila svoji vodní vílu.

Řada reflektivních poznámek, zejména v první části (Uá a moje já, Respektovat a být respektován), svědčí o tom, že portfolio se pro Lenku stalo užitečným nástrojem sebereflexe. Během studia jí sloužilo jako zrcadlo v pohledu na vlastní profesní dovednosti. Za př́klad způsobu sebezpytného pohledu může posloužit seminární práce z pedagogicko-psychologické diagnostiky. Je zde patrné, že reflektivní poznámky nevznikaly ve stejnou dobu, autorka je přidávala $\mathrm{v}$ různém čase. Na titulní straně práce najdeme ručně psanou poznámku: „Špatný příklad. Takhle ne!“, což působí jako okamžitá reakce na hodnocení kvality vypracované seminární práce. Později přidaný lepicí lístek obsahuje věcně strukturované doporučení pro budoucnost, kdy bude Lenka diagnostikování v pozici učitelky sama provádět: „Zvolit správnou metodu diagnostikování a držet se jí. Podrobně uvádět metody. Mít důkazy 
ke svému tvrzení!!“ Lze zde sledovat posun od emotivního, polarizujícího způsobu uvažování $\mathrm{k}$ věcnějšímu myšlení, které se opírá o odborné zásady a relevantní teorii.

Pevnost Lenčina rozhodnutí stát se učitelkou mateřské školy odráží již esej Co mi dala vstupní pedagogická praxe. Lenka přiznává počáteční nejistotu, která pramení z názorů v jejím okolí (práce s dětmi „není jedna z nejlepších“, učitelky mají nízký plat atd.), ale i svou „lásku a náklonnost k dětem“, kterou si chce během vstupní praxe potvrdit. Pozdější reflektivní poznámky ukazují změny v Lenčině pojetí: k dětem cítí nejen náklonnost pro jejich roztomilost, ale chce je také vést $\mathrm{k}$ „samostatnosti, spolupráci a toleranci“. Začíná užívat odborné pojmy a termíny: laické označení „různé činnosti“ později upřesňuje termíny „volná hra, polořízené a řízené činnosti“. Lenka se na vstupní praxi poprvé setkala s asistentem pedagoga. Z jejího pozdějšího komentáře vyplývá, že nyní jako učitelka v mateřské škole sama s asistentem účinně spolupracuje. Závěrečná poznámka odráží Lenčino vnímání významu praxe: pohled začínajícího studenta na práci učitelky může být zkreslený, „protože nezná žádnou teorii. Proto je dobré v praxích pokračovat až k samotnému konci studia."

Lenčin názor na osobnost učitele byl na začátku studia pochopitelně idealistický, neovlivněný předchozí zkušeností, přesto zde najdeme určitá témata, která představují trvalé leitmotivy Lenčina profesního směřování. V eseji Jak si představuji dobrou učitelku / dobrého učitele mateřské školy se zamýšlí nad autoritou učitele, která by „neměla být založena na strachu dětí", ale na nadhledu a rozhodnosti, schopnosti rychlého rozhodování a klidného uvažování. Téma vzhledu učitelky shledává s odstupem dvou let jako nepodstatné: „Děti se s tetováním setkávají i u rodičů." Pozdější reflektivní poznámka zachycuje posun od touhy být jako učitelka oblíbená směrem k profesním dovednostem: učitel by měl především „vytvořit plán pro děti tak, aby je zaujal, motivoval a rozvíjel, jak nejlíp to jde“. I na dalších místech zachycují reflektivní poznámky posuny a prohlubování Lenčina chápání problematiky předškolního vzdělávání. Mezi své klady zařazuje „dochvilnost, empatii, zpětnou vazbu, efektivní komunikaci, motivaci, plánování a schopnost spolupracovat s rodiči a kolegy“; chtěla by se zlepšit v diagnostice a také v komunikaci s dětmi přestat používat odborné termíny, byt' se odborné pojmy již staly trvalou součástí jejího profesního uvažování. 
Jiným př́́kladem snahy o získání profesního nadhledu je sada lepicích lístků přiložená $\mathrm{k}$ formuláři hodnocení pedagogických praxí v první části portfolia. Lenka zde konkrétně pojmenovává, kde vnímá své zlepšení a co by ještě chtěla „zapracovat" během jednotlivých semestrů, opírá se zde o hodnocení provázejících učitelek v jednotlivých ročnících. Reflektivní poznámky zde tvoří přehlednou evidenci Lenčina profesního posunu. Na první praxi provázející učitelka doporučuje „zapracovat na odstranění ostychu, více zapojovat do dění". Na druhé praxi došlo ke zlepšení komunikace s učitelkou a objevuje se poznámka „úsměv a empatie“. Jako nový cíl si Lenka stanovuje zaměřit se na motivaci dětí a také mít „přehled o celé tř́iě, nevěnovat se jen jednotlivým dětem". Na třetí praxi roste její sebevědomí, lépe navazuje s dětmi kontakt, ostych je menší. Chce začít pracovat s Rámcem profesních kvalit učitele mateřské školy (Syslová \& Chaloupková, 2015). Na čtvrté praxi už je schopná kontrolovat celou třídu, při plánování činností vychází z RVP a ŠVP školy. Chce se naučit improvizovat, zaměřit se na různorodější aktivity a využívat aktuální dění ve třídě. Lenčin profesní posun lze sledovat i v poslední části portfolia, kde $\mathrm{v}$ tematických plánech autorka propojuje nabyté vědomosti a získané dovednosti. Každý týdenní plán obsahuje část, ve které navrhuje možnosti zapojení rodičů a uplatňuje své diagnostické dovednosti. Všímá si například úchopu tužky či komentuje schopnost dětí spolupracovat a udržet pozornost.

Reflektivní poznámky a komentáře dokládají upřímnou snahu a následný odborný posun autorky, zdá se, že se Lenka v práci učitelky mateřské školy našla. Jde o př́klad procesně-bilančního portfolia, jež obsahuje převzaté materiály (hodnoticí a sebehodnoticí formuláře, fotokopie z knih a metodických materiálů, fotokopie ŠVP, vzorový dopis rodičům atp.) „které studentka vyhodnocovala jako užitečné pro svou budoucí výuku" (Tomková, 2018, s. 196). Lenčino portfolio sice nevyniká originálním členěním či osobitostí pojetí, ale dobře dokládá potřebu poctivě budovat partnerský přístup k dětem, potřebu nutně se posunout od „všeobjímající lásky k dětem“ ke strukturovanému profesnímu uvažování. Umožnilo své majitelce vracet se, promýšlet a komentovat předchozí zkušenost, vytvořit most mezi minulostí a budoucností, a tím rozvíjet profesní kompetence a dovednosti role učitelky mateřské školy.

\section{Monika jako autorka originálního portfolia}

Moničino portfolio patří k jednomu z nejobsáhlejších, obsahuje 187 listů. Jeho struktura zahrnuje pohled Moniky na sebe (Kdo jsem já), postoj ke skupině (Já a tř́́da) a k dětem (Já a dítě). Pohled na sebe je doplněn pohledem 
druhých a v závěru portfolia můžeme najít oblast Já a budoucnost, ve které jsou vloženy cíle, kterých by chtěla dosáhnout v nejbližší budoucnosti. Monika svůj přístup popisuje následovně: „Já jsem to vždycky stavěla kolem mě, vždycky to bylo já a něco. A jediné, co tam bylo (...) z té druhé strany, bylo, jak mě vidí druzí."

Monika započala svoji profesní dráhu již na střední pedagogické škole. To se odráží v poměrně vyzrálém názoru na profesní jednání učitelky, který vyjádřila v eseji na téma Jak si představuji dobrého učitele v mateřské škole z prvního roku studia. Učitel by neměl děti ztrapňovat, měl by respektovat jejich individualitu. Monika si již na začátku studia uvědomuje význam diagnostických dovedností učitele. Považuje za důležité dlouhodobě sledovat projevy dětí a vést si o nich záznamy, ty by pak využila, „aby mohla s dětmi správně pracovat". Dále se v eseji zamýšlí nad tématem spolupráce s rodinou, učitel by měl s rodiči jednat s respektem, měl by s nimi spolupracovat v zájmu dítěte.

Z eseje Jak si představuji dobrého učitele v mateřské škole však vyplynula i jakási naivní představa o osobnosti učitelky. Podle Moniky by učitelka neměla mít „vyzývavé oblečení, dlouhé umělé nehty“, neměla by být „přehnaně nalíčená", ale také by se neměla opíjet apod. Měla by mít „pokojný hlas a vlídné vystupování, ale také umět zařídit, aby ji děti poslouchaly“.

Své představy reflektuje s odstupem času na lepicím lístku z listopadu 2019 takto: „I dneska souhlasím se vším, co jsem tehdy napsala, ale je to jen mizivá část toho, co by měl učitel v MŠ vědět." Svůj pohled na učitele doplňuje o nutnost diferencovat vzdělávání („podávat informace více způsoby“), plánovat vzdělávací práci, o dobré komunikační dovednosti učitele využitelné jak při komunikaci s dítětem („být dobrý mluvní vzor“), tak při komunikaci s rodiči a okolím, a o jeho diagnostické dovednosti.

Specifickou oblastí zájmu této studentky je waldorfská pedagogika. 0 svém zájmu a zkušenostech $\mathrm{s}$ tímto alternativním programem se zmiňuje v eseji ze vstupní pedagogické praxe. Můžeme na něj usuzovat z osvědčení o dalším vzdělávání i z vysvědčení o maturitní zkoušce, kterou absolvovala na střední škole - waldorfském lyceu. Dalším dokladem je seminární práce z volitelného předmětu Alternativní směry v mateřské škole. $V$ ní se můžeme dovědět, že její zájem zřejmě pramení z osobní zkušenosti, nebot' sama absolvovala waldorfskou základní školu. Tato její dlouhodobá orientace k waldorfské 
pedagogice je zřetelná i z cílů, které si klade v poslední části Já a budoucnost. V tomto jejím zájmu můžeme zřejmě nalézt také prameny orientace na dítě.

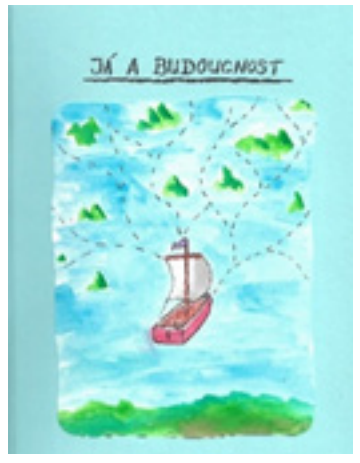

V části portfolia Já a tř́da lze dobře sledovat profesní zrání Moniky. Nacházíme zde množství didaktických seminárních prací, které často postrádají reflektivní či hodnoticí prvky nebo jde o poměrně povrchní či popisná hodnocení: „Z mého pohledu se mi aktivita povedla dle očekávání", píše 8. 11. 2018. Ta nacházíme až s odstupem času, kdy formou nalepených lístků zpětně reflektuje svoje zkušenosti a profesní dovednosti: „Vymyslet, jak si děti můžou samy zkontrolovat, zda aktivitu udělaly správně, a nepotřebují účast učitelky," poznamenává na lístku o rok později, v listopadu 2019.

Tato vzrůstající podpora samostatnosti dětí a rozvíjející se role facilitátora zřejmě souvisí s hodnoceními vyučujících, které má Monika ve svém portfoliu také. Při první souvislé praxi (4. semestr) se v hodnocení vyučujícího objevuje, že má problémy s podporou samostatnosti dětí a jejich spolupráce s ostatními. V další souvislé praxi v pátém semestru již můžeme sledovat, že si tento nedostatek s podporou provázející učitelky uvědomila a začala na něm pracovat: „Snažila jsem se docílit toho, aby si děti samy zjistily, co mají dělat, a šly si pro vysvětlení k dětem, které ten úkol už dělaly."

Obdobný vývoj v uvažování i v samotné realizaci můžeme sledovat např̀ u částečně řízených aktivit. Ve čtvrtém semestru uvádí v sebereflexi kritické poznání, že má s organizací těchto činností problém, nebot' „většina částečně řízených činností vždycky skončí jako řízené“. V pátém semestru sice stále přiznává nejistotu s touto organizační formou, ale v zadání činností je již patrnější lepší porozumění takto organizovaným činnostem.

Fotografie uvedené v některých seminárních pracích dokládají vrůstající tvořivý př́ístup k plánování a realizaci vzdělávacích aktivit. Reflexe didaktické praxe z výtvarné výchovy ze 6 . semestru ukazuje, že již dokáže analyzovat a hodnotit př́istupy učitelky: „Dle mého názoru nedává učitelka dětem dostatečný prostor na vyjádření a kreativitu, často jim do práce slovně zasahuje a nutí je dotvářet výtvory dle její představy." Z většiny lístků s reflektivními poznámkami lze vyčíst větší vnímavost k možnostem dětí: „... komplikovaný 
postup, děti to samy nezvládnou“, i uvědomění si jejich práva rozhodnout se a vybrat si z nabízených aktivit podle svého přání.

$\mathrm{Z}$ dalších hodnocení praxe ve třetím roce studia můžeme vyčíst, že provázející učitelka z mateřské školy i vyučující z fakulty oceňují její citlivý přístup k dětem a doporučují „slevit z nároků na sebe“. V posledním roce studia provázející učitelky oceňovaly aktivní zapojování do činností, mnohdy i „nad rámec svých povinností". 0 jejím proaktivním přístupu i k výuce svědčí také zapojení do ověřování nového diagnostického nástroje pro děti předškolního věku, o kterém se můžeme dočíst v potvrzení o vykonání odborné praxe v pátém semestru.

Podle Tomkové (2018, s. 196) bychom mohly portfolio označit jako originální, nebot’ má promyšlenou strukturu a reprezentuje originální artefakty studentky.

\section{Petra jako autorka živého profesního portfolia}

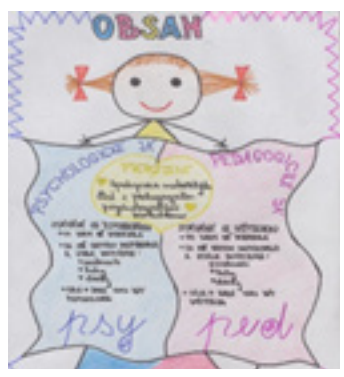

Petřino portfolio se skládá z 86 listů. Má výrazný grafický design. Petra hojně využívá grafické modely a mentální mapy. Struktura portfolia je na první pohled originální, promyšlená a logická. Je zde patrný ohled na čtenáře i záměr propojit své dosavadní profesní zkušenosti, tj. studium psychologie na fakultě sociálních studií MU s učitelstvím mateřské školy. Petra vysvětluje svůj prrístup k tvorbě portfolia takto:

Mám tam tři části - psychologické já, pedagogické já a propojení. A každá část má několik podbodů - cíle, jaká chci být pedagožka nebo psycholožka, potom co mě cestou inspirovalo a inspiruje, kam řadím osobnosti, knihy a články a na začátku je, co už jsem dokázala - různé certifikáty, diplomy, seminární práce, ukázky z praxe.

Z celého portfolia vyzařuje snaha propojovat obě složky profesní přípravy, pedagogickou a psychologickou, což kulminuje v poslední mentální mapě, ve které Petra vidí sama sebe z poloviny jako pracovnici v pedagogicko-psychologické poradně a z poloviny jako učitelku mateřské školy. Celým portfoliem prostupuje Petřin sklon zamýšlet se nad sebou, nad budoucností, nad svými profesními dovednostmi i nad tím, jak ji ovlivňuje její okolí. 
Od první, vstupní pedagogické praxe je možné pozorovat nadšení z práce s dětmi a současně poměrně jasnou představu, jaký vzdělávací program a př́ístupy jí imponují: „Věnuji se tak důkladně popisu první školky, protože mě zaujala nejvíce a velmi se ztotožňuji s jejím zaměřením. Líbí se mi, jaká zde panuje volnost. Děti mají dané úkoly, které během týdne plní, ale mohou na nich pracovat, kdy chtějí." Toto nadšení se týká mateřské školy s daltonským programem. Vybrala si ji i jako místo realizace další praxe, kterou studentky vykonávají tři semestry ve stejné mateřské škole. I po roce se v jejím sebehodnocení dovídáme, že se tam cítí „příjemně a užitečně“. Zájem o daltonský plán lze spatřit také $\mathrm{v}$ části portfolia, kam zařadila medailony osobností, které ji ovlivnily; jednou z nich je Helen Parkhurstová.

Z hodnocení provázející učitelky i vyučující z fakulty lze vysledovat, že Petra patř́ ke studentům, kteří nabízí svoji pomoc a nezůstávají pouze v rovině plnění svých povinností, ale jdou i nad jejich rámec: „Oceňuji ochotu a vstřícnost nejen v MŠ, ale i na vysoké škole.“ Dobré hodnocení Petra získala i v posledním ročníku studia, na poslední praxi: „Pozitivně lze hodnotit vše př́stup k dětem, připravenost, nápady, spolupráci s učitelkou, ochotu pomoci, př́ijemné vystupování (...) chtěli bychom ji do kolektivu."

Jak vyplývá z hodnoticích formulářů za druhý a třetí semestr, Petra má problémy s hlasitostí a intonací mluvního projevu včetně používání efektivní komunikace. V efektivní komunikaci jde zejména o využívání popisného jazyka; tyto problémy přetrvaly až do konce studia. Petře také činí obtíže formulovat konkrétní cíle profesního rozvoje. Ve 4. semestru se s oporou o Rámec profesních kvalit učitele mateřské školy (Syslová \& Chaloupková, 2015) podařilo Petře vyhodnotit její silné stránky a současně poměrně jasně formulovat oblasti, ve kterých bude potřeba dalšího rozvoje:

Vyjádření důvěry dětem se mi začíná dařit - během praxe jsem u různých úkolů používala výroky typu „věřím, že to zvládneš“ (...) Zvládání chování dětí ve třídě spatřuji jako svoji nejdůležitější rozvojovou oblast. Ráda bych užívala efektivní komunikaci, ale zatím se mi to moc nedaří. $V$ případě potřeby děti „usměrnit“ zůstávám zatím spíše u rozkazovacího způsobu, jelikož mi dělá potíže vymyslet v tu konkrétní chvíli způsob, jak bych to mohla ř́ci jinak.

Petra se ráda vyjadřuje obrazně, často užívá slovní metafory, což doplňuje grafický způsob zachycení vlastních myšlenek v mentálních mapách. V reflexích nazvaných Já s Lůcou proti světu a Moje mušketýrky odhaluje svoje nitro, popisuje, jak porozumění s některými spolužačkami ovlivnilo její život 
i př́stup ke studiu: „Každý úkol / projekt / seminární práce, na kterých jsme dělaly spolu, byl ukázkou mentálního napojení jedné na druhou, které dosáhlo svého vrcholu při zpracování tematického plánu k naší společné praxi.“ Dokáže mistrně využít slova k vykreslení svých pocitů a hlubokého sociálního cítění:

Zůstaly jsme tři mušketýrky, já, Lucka a Míša. Každá z těch dvou je jedinečná: Míša je věčné sluníčko, které bere život s nadhledem (...) Lủca je naše opatrovnice vždycky se stará o druhé (...) Nedovedu si vůbec představit, že bych se probojovala studiem na PdF bez nich dvou.

Výrazným rysem Petřina portfolia je četba zahraniční literatury, na kterou se odvolává na několika místech. Jde o seznam textů (knih i článků), které uvádí ve složce Psychologické já i v ukázce Moje pedagogická knihovnička v oddíle Pedagogické já, kde má zařazenu i fotografii s několika anglickými tituly.

Portfolio Petry tvoří syntetický a originální obraz autorky a z hlediska vymezených kritérií (Tomková, 2018, s. 194) jej lze klasifikovat jako živé profesní portfolio, které je bilanční a autentické. Je v něm patrná snaha integrovat svou profesní zkušenost a v hlubokém záběru zachytit cesty, které „vedou k učitelství a pomáhají jí připravit se dobře na profesi“.

\subsection{Vnímání portfolia jako nástroje profesionalizace}

Při hledání odpovědi na třetí specifickou otázku Uak studentky vnímají portfolio $v$ kontextu svého profesionalizačního rozvoje?) jsme vycházely z analýzy ohniskové skupiny uskutečněné na konci kurzu a čtyř individuálních rozhovorů s Barborou, Lenkou, Monikou a Petrou, které jsme vedly po absolvování státní závěrečné zkoušky. Vymezily jsme čtyři okruhy, které respondentky identifikovaly jako významné jak pro vytváření portfolia, tak i pro jeho budoucí využití. Označily jsme je: (1) porozumění obsahu portfolia, (2) autentický přístup, (3) př́ležitosti k učení a (4) využití portfolia.

\section{Porozumění obsahu portfolia}

Jak jsme již uvedly, aktivita V-Ch-D ukázala sklon studentek k heteronomnímu přemýšlení o portfoliu. Studentky se na začátku kurzu potýkaly s otázkou, jak svoje portfolia uspořádat a jaké artefakty sem zakládat. Monika v rozhovoru po SZZ uvádí, že než absolvovala kurz, tak měla v portfoliu jen „seminárky, bez reflexí, nebylo to nijak strukturované, prostě to byla složka 
plná složek“. Petra popisuje situaci takto: „Než jsem tento předmět měla, tak jsem vůbec netušila, co všechno do portfolia patří, komu ho mohu ukazovat, k čemu vlastně je."

V ohniskovém rozhovoru řada studentek zmiňovala posun ve svém přístupu k obsahu i struktuře portfolia, které přestaly vnímat jako požadavek daný vyučujícími, ale pochopily, že obsah i struktura jsou věcí jejich rozhodovací kompetence: „Uvědomila jsem si, že obsah portfolia není nikým určen: takhle to je a takhle to musí mít všichni. Stejně. Je to moje, mohu si to udělat podle

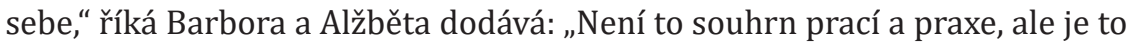
ukázka mě." Pro Cecilii se skutečnost, že jen ona je zodpovědná za výslednou podobu portfolia, stala zdrojem tvořivosti: „Mohu si tam kreslit, zkrátka, co budu chtít. Když jsem si toto uvědomila, začalo mě jeho vytváření bavit." Daniela si uvědomuje nutnost koncepce a promýšlení výsledné podoby: „Do portfolia si mohu dát, co chci, pokud si to dokážu obhájit před sebou i před ostatními.“ Eva svou zkušenost zobecňuje: „Portfolio by mělo být srozumitelné a přehledné, je to obraz jedinečnosti každého člověka."

\section{Autentický prístup}

Tomková (2018, s. 137) považuje práci s autentickými materiály za účinný způsob, jak motivovat studenty při hledání vlastní koncepce portfolia. Přemýšlení o nich vede ke generování otázek, podněcuje inspiraci a představuje cestu $\mathrm{k}$ vlastní původnosti, ryzosti, hodnověrnosti a originalitě. Studentky našeho kurzu opakovaně uváděly, že postupně začaly portfolio vnímat jako „vlastní majetek“: „Je to osobitý dokument, který zachycuje, kdo jsem, jak myslím a kam směřuji ve svém profesním životě. 0 tom, co v něm bude, rozhoduji jen já,“ ‘̌́iká Gabriela. „K portfoliu nyní přistupuji mnohem zodpovědněji, jako k souboru, který bude mým pomocníkem,“ doplňuje představu o potenciálu portfolia Františka.

Čtyři studentky měly možnost tento potenciál uplatnit u SZZ. Lenka svou zkušenost popisuje takto:

Co jsem dneska předvedla, tak já jsem na sebe strašně pyšná, protože jsem tam (...) použila strašně moc materiálů z práce, ze školky a dokázala jsem reagovat pohotově, a to se mi strašně líbilo. (...) Kdybych neměla tak připravené portfolio, tak si asi tak nevěřím. 


\section{Monika dodává:}

Měla jsem tam konkrétní papíry, o které jsem se mohla opřít, a i mi to přidalo víc klidu. Když jsem se u něčeho zamotala, a pak jsem přešla k něčemu hmatatelnému, tak mi to pomohlo.

I pro ostatní se portfolio u SZZ stalo zdrojem jistoty: „S tím portfoliem je to takové snazší. Sice to zabere dost času (...) shánět si ty materiály a poskládat si to do takové posloupnosti, která by nám vyhovovala, ale (...) je to určitě super takto," konstatuje Lenka.

\section{Př́ležitosti $k$ učení}

Studentky často - co do četnosti výroků šlo o nejčastěji zmiňovaný okruh mluvily o tom, jak si díky práci s portfoliem začaly uvědomovat změny ve svém př́ístupu k učení. Petra popsala posuny svého chápání během studia:

$\mathrm{V}$ prvním ročníku jsem byla hodně nekritická a bylo to vidět $\mathrm{v}$ dokumentech v portfoliu, kde mám třeba reflexi prvního ročníku z praxe. A když se zamyslím nad praxí ted', je tam vidět ten posun, co mi teoretické znalosti už umožňují studovat, např. prvky neefektivní komunikace ve tř́dě.

Lenka si začala uvědomovat svoje silné a slabé stránky: „Když jsem to procházela, tak jsem zjistila, co už zvládám, co nezvládám, co jsem ráda, že tam mám, nějaký ten podnět k tomu, co mě postrčí, co mi pomůže." Portfolio umožnilo zachytit změny, ke kterým během studia došlo: „Že jsem úplně jiný člověk, než jsem byla, když jsem sem přišla. Co se týče vědomostí, to určitě. Co se týče zkušeností, ale i určitě, co se týče celkového pohledu na svět, na děti a na to, co děláme," shrnuje Lenka. Monika pojmenovává konkrétní oblasti proměny svého profesního myšlení:

... že ty první seminární práce jsou takové i třeba po té teoretické části i jenom tak vlažné (smích) a pak už jsem se víc dostávala do toho i jak třeba i jakým jazykem psát (...) v těch aktivitách, že se třeba pozměňovaly od těch původních (...) že jsem si něco vzala z těch teorií, aby to pro to dítě bylo i lepší.

Portfolio umožnilo kriticky přemýšlet o vlastních profesních dovednostech, v př́ípadě Moniky např́íklad nahlédnout na úroveň diagnostické kompetence:

I když ty základní znalosti o integrovaných dětech mám, tak jsem si uvědomila při tom, jak jsem se víc učila na ty státnice, že bych si asi nebyla úplně jistá, kdybych 
dostala do tř́ídy třeba autistické dítě nebo s nějakým jiným problémem, takže na to se zaměřit a najít si třeba nějaký kurz, kde by se věnoval vysloveně, konkrétně poruše nebo něčemu takovému.

Studentky se shodovaly, že portfolio představovalo významnou oporu při přípravě na SZZ. Petra popisuje, jak postupovala:

Někde jsem si vzala i knížky, třeba když bylo potřeba definovat konstruktivismus, tak jsem si přečetla, co všechno pod něj spadá a potom jsem použila nějakou konkrétní aktivitu, kterou jsem dělala s dětmi, abych ho demonstrovala.

Monika se zamýšlí nad tím, jak portfolio ovlivnilo její výstup u SZZ: „Myslím si, že právě provázání té teorie s tím portfoliem hodně pomohlo k tomu, že už to není jenom takové to memorování, co do týdne zapomenu, ale je tam i ta teorie. Že takové... konečně (smích) taková proměna trošku toho školství.“

Nezanedbatelnou úlohu v procesu hledání klíče ke struktuře vlastního portfolia, při nacházení jeho podoby, hrála písemná i ústní reflexe od ostatních, což připomíná Barbora:

Kolegyně mi tam napsaly, že by tam bylo možné ještě něco doplnit (...) tak jsem to tam zařadila. A bavily jsme se o tom, co tam která máme zařazené, a došly jsme na spoustu věcí. Každá si psala poznámky, co by tam ještě mohla zařadit (...) a bylo právě velice dobré, že se člověk mohl nad tím zamyslet, mohl to s někým rozebrat, nemusel být na to sám.

\section{Využití portfolia}

Z odpovědí studentek vyplynulo, že s portfoliem počítají i do budoucna, nejčastěji je plánují využít při žádosti o zaměstnání. Dvě z nich - jako čerstvé absolventky - již tuto možnost využily; jejich portfolio se dokonce stalo inspirací pro vedení mateřské školy i budoucí kolegyně:

Portfolio se jim velice líbilo a zaujalo je, nechávali si ho tam na týden a prohlíželi si ho všichni. Takže zjistila jsem, že to asi funguje nebo minimálně zaujmu i toho potencionálního zaměstnavatele, takže ho proměnit na takové portfolio reprezentační,

plánuje Monika. Barbora mluví o nutnosti změn:

V př́padě, že bych nastupovala na jinou školku nebo měla zájem o jiné zaměstnání, tak bych to teda protř́ídila, neměla bych to podle těch státnicových otázek, ale 
nechala bych tam, co si myslím, že je důležité a zásadní pro praxi a vzala bych to s sebou na pohovor.

Pro Lenku se portfolio stalo trvalou součástí její profesní osobnosti, což mělo vliv i na její kolegyně:

Půjčovala jsem ho hodně kolegyním ve školce, protože jsme dostaly během karantény úkol si vytvořit profesní portfolia, takže hodně se jich motivovalo, hodně se mě ptalo, proč to tak mám. Já ŕíkám, protože jsem si to zvolila a neznamená, že to musí mít jako stejně. Ale vím, že aspoň třičtvrtě věcí, co tam mám, si tam nechám. (...) Určitě ho budu pořád nějak inovovat.

Materiály uložené v portfoliu nezachycují jen minulost, ale mohou představovat inspiraci do budoucna, jak zmiňuje Barbora:

Mám tam třeba PREDICT, který bych velice ráda začala používat v mateřské školce, všechny tři ty části. Mám ho tady, takže můžu ho prezentovat třeba paní ředitelce, můžeme se na tom domluvit, jak vypadá. (...) Ted’ tam mám spoustu věcí, na které se chci zaměřit a chtěla bych je využívat dál.

Petra plánuje portfolio využít při studiu navazujícího magisterského studia:

Jestli budu pokračovat na magisterském studiu (...) tak ho určitě využiji tak, že tam přidám materiály, které vzniknou během studia. A kdybych se nedostala nebo nepokračovala, tak bych ho využívala, až začnu učit přímo v praxi.

Jak portfolio ovlivnilo průběh SZZ jsme se zeptali také zkoušející z katedry psychologie. Z jejího pohledu je využití portfolia u SZZ náročnější nejen pro studenty, ale i pro zkoušející. Uváděla, že pro ni bylo těžké naladit se při státnicovém pohovoru na studentku, ale současně i na kolegyni, aby nedocházelo k tříštění tématu nevhodnými nebo podobnými otázkami. Oceňovala propojení teorie s praxí, jehož výsledkem je „hlubší porozumění“. Zapojení portfolia do SZZ vede podle ní „k promyšlení a propojení do hloubky, ale ne u všech. Část studentek sklouzne jen $\mathrm{k}$ té zkušenosti. A my se snažíme je k té teorii nějakým způsobem vrátit." Za významný př́nos považuje, že odpovědi s oporou portfolia nejsou „až tak schematizované, nejdou po pojmech, po otázce“. Dříve se často setkávala s tím, že studentky neměly „svoji koncepci. Nějakou strukturu, kterou by měly promyšlenou." A to se nyní změnilo. 


\section{Diskuze a závěry}

Naším cílem bylo blíže prozkoumat a popsat, jak příprava profesního portfolia ovlivňuje proces učitelské profesionalizace a rozvoj pedagogické individuality studentek učitelství pro mateřské školy. Zkoumání jsme provedly v rámci předmětu Tvorba profesního portfolia, kde jsme se zaměřovaly jednak na výukové strategie kurzu, jednak na analýzu finálních portfolií vybraných studentek.

Metodologický přístup formou akčního výzkumu umožnil lépe porozumět procesům, které v rámci kurzu probíhají, zaměřit se na vyhodnocení vlivu používaných strategií výuky. Za klíčové zde považujeme kooperativní aktivity, vrstevnické hodnocení a vzájemné sdílení zkušeností. Kooperace v rámci výuky jednotlivé studentky osobně zapojila. Rozšířila jejich interakce, což vedlo k vytvoření pozitivního klimatu skupiny a k rozvoji interpersonálních dovedností. Sdílení zkušeností a vrstevnické hodnocení prohloubily vztahy a posílily sebedůvěru jednotlivců (Kasíková, 2015b; Tomková, 2018, s. 23). Efektivitu jednotlivých zvolených strategií nelze vyhodnotit zcela jednoznačně. Lze však konstatovat, že u studentek došlo k prokazatelnému posunu od heteronomního přemýšlení k autonomnímu uvažování o portfoliu; mezi studentkami prezenčního a kombinovaného studia se neprojevil významný rozdíl.

Na základě provedené analýzy lze konstatovat, že v porovnání s jinými výzkumy (Syslová, 2015, 2016) studentky dosahovaly vyšších úrovní myšlenkových operací. Nelze však jednoznačně rozhodnout, zda k tomu došlo vlivem jmenovaných výukových strategií. Zjištění vyvolávají otázku, zda by rozdíly v úrovni myšlenkových operací byly prokázány i před kurzem. Domníváme se však, že zvolené strategie umožnily studentkám aktivně zapojovat vyjadřovací schopnosti a hledat adekvátní způsob formulování svých myšlenek. Písemné hodnocení jiného portfolia umožnilo propojit teoretické poznatky s konkrétním případem. Úkol popsat, v čem je hodnocené portfolio jedinečné, co je jeho jádrem, co je podstatné a co chybí, vyžadoval používat pojmy a odborné termíny, komplexně a kriticky formulovat vlastní názor i uplatnit poznanou teorii (Grecmanová et al., 2000, s. 24).

Analýza vybraných portfolií přinesla čtyři individuální profesionalizační příběhy (Painter, 2001, s. 31). Umožnila zachytit proces budování profesní identity studentek (Spilková et al., 2004, s. 147-149) v rovině jejich schopností, osobního zaměření či vnitřního přesvědčení. Stali jsme se svědky procesu utváření profesního uvažování, patrné byly zejména posuny v oblasti 
komunikačních a diagnostických dovedností, schopnosti formulovat cíle, ztráta ostychu či hledání vztahu k dětem. Postoje spojené s předchozí zkušeností v podobě intuitivních názorů (např. na osobnost učitele mateřské školy) se začaly vlivem četby odborné literatury, kontaktem s realitou mateřské školy i přístupem provázejících učitelek a fakultních vyučujících proměňovat a postupně se stabilizovaly ve vlastní pojetí založené na argumentaci a kritickém pohledu na vlastní pedagogické dovednosti. Ukázala se osobní jedinečnost každého příběhu, která se však odvíjí v kontextu společného studia a jeho sjednocujících výstupů (zejména Profil absolventa a Rámec profesních kvalit učitele mateřské školy).

Výzkumné šetření umožnilo zachytit krystalizační proces profesního myšlení, které bylo utvářeno skrze systematickou sebereflexi a vzájemné hodnocení. Stále patrnější byla potřeba chápat souvislosti, rozumět příčinám a následkủm vlastní činnosti, kriticky prozkoumávat vlastní př́ístupy, včetně přijetí zodpovědnosti za svá rozhodnutí i jednání (Spilková et al., 2004, s. 147). To považujeme za prokazatelné znaky restrukturovaného myšlení o profesi, které odráží hlubší porozumění profesním dovednostem i další porozumění principům předškolního vzdělávání a profesním dovednostem učitele mateřské školy.

Vzhledem k tomu, že se jednalo o volitelný předmět, lze předpokládat, že se do kurzu přihlásily studentky, které tematika portfolia zajímala, což mohlo ovlivnit výsledná zjištění. Pro podporu rozvoje profesní identity všech studentů by bylo vhodné, aby obdobné strategie, včetně intenzivní práce s portfoliem, byly zařazeny také do výuky povinných předmětů. Volitelný předmět by $\mathrm{z}$ tohoto pohledu neměl nahrazovat systematickou podporu studentů, která by měla směřovat $\mathrm{k}$ autoregulaci, přijetí odpovědnosti za vlastní učení. Volitelný předmět by neměl plnit funkci formativní, to by mělo být běžnou součástí povinných předmětů, měl by nabízet spíše nástavbu v podobě završení, sumarizace oborových témat. Výsledky šetření se pro nás stávají výzvou pro úpravu výuky ostatních předmětů i přesvědčování dalších vzdělavatelů budoucích učitelů mateřských škol o prínosech akčního výzkumu ve vlastní pedagogické činnosti.

Na samý závěr se chceme vrátit k našemu původnímu záměru, kterým bylo obohatit diskuzi o podobě konkrétních strategií ve studijním programu Učitelství pro mateřské školy. Výsledky ukazují, že portfolio se stává centrálním prvkem učení a profesionálního posunu. Studentky k tvorbě portfolia přistupovaly zodpovědně, výrazným rysem práce se stalo systematické propojování teorie a praxe a rozvoj schopnosti argumentovat, což žádoucím 
způsobem ovlivnilo podobu SZZ. Práce s portfoliem vedla studentky k vytvoření vlastních učebních strategií, které při přípravě na SZZ funkčně uplatnily. Výsledkem byly autentické individuální přístupy k učení s originálními výstupy, jejichž cílem nebylo naplnit požadavky zkoušejících, ale ukázat, kdo jsou a jakými učitelkami by chtěly a mohly být.

\section{Literatura}

Bloom, B. S. (Ed.). (1956). The taxonomy of educational objectives. The classification of educational goals, Handbook I. David McKay Company.

Burkovičová, R. (2012). Profesní činnosti učitelů mateřských škol a jejich výzkum. Ostravská univerzita v Ostravě.

Dytrtová, R., \& Krhutová, M. (2009). Učitel: příprava na profesi. Grada.

Grecmanová, H., Urbanovská, E., \& Novotný, P. (2000). Podporujeme aktivní myšlení a samostatné učení žáků. Hanex.

Havlíčková, M. (2012). Tvorba a využití profesního portfolia pro formování odborných kompetencí studentů. Vyšší odborná škola sociálně právní.

Hegrová, I. (2014). Využití portfolia dítěte jako diagnostického nástroje při přechodu z MŠ na ZŠ. Komenský, 138(4), 47-50.

Hendl, J. (2005). Kvalitativní výzkum: základní metody a aplikace. Portál.

Janík, T., Slavík, J., Mužík, V., Trna, J., Janko, T., Lokajíčková, V., Lukavský, J., Minaříková, E., Sliacky, J., Šalamounová, Z., Šebestová, S., Vondrová, N., \& Zlatníček, P. (2013). Kvalita (ve) vzdělávání: obsahově zaměrený prístup ke zkoumání a zlepšování výuky. Masarykova univerzita.

Kaliszewska, M. (2013). O kvalitě a hodnotících kritériích akčního výzkumu. Pedagogická orientace, 23(4), 587-596.

Kasáčová, B. (2005). Reflexívna výučba a reflexia v príprave učitela. PF UMB.

Kasíková, H. (2015a). Didaktika vysoké školy a teorie učitelského vzdělávání jako zdroj jejího rozvoje. Aula, 23(1), 36-57.

Kasíková, H. (2015b). Proměna vysokoškolské výuky. Studia Paedagogica, 20(2), 81-103.

Lukášová, H. (2015a). Portfolio začínajícího učitele. Univerzita Tomáše Bati.

Lukášová, H. (2015b). Učitelské sebepojetí a jeho zkoumání. FHS UTB.

Lukášová, H., Svatoš, T., \& Majerčíková, J. (2014). Studentské portfolio jako výzkumný prostředek poznání cesty $k$ učitelství. Univerzita Tomáše Bati

Nezvalová, D. (2003). Akční výzkum ve škole. Pedagogika, 53(3), 300-308.

NIDV. (2013). Metodika pro učitele k přípravě a vedení dokladového portfolia v kariérním systému.

Painter, B. (2001). Using teaching portfolios. Educational Leadership, 58(5), 31-34.

Paulson, F. L., \& Paulson, P. R. (1996). Assessing portfolio using the constructivist paradigm. In Student portfolios. A collection of articles (s. 27-46). IRI / SkyLight Training and Publishing.

Piaget, J., \& Inhelderová, B. (2007). Psychologie dítěte. Portál.

Píšová, M. (2005). Klinický rok: procesy profesního rozvoje studentů učitelství a jejich podpora. Univerzita Pardubice.

Píšová, M. (Ed.). (2007). Portfolio v profesní př́ípravě učitele. Univerzita Pardubice.

Píšová, M., Najvar, P., Janík, T., Hanušová, S., Kostková, K., Janíková, V., Tůma, F., \& Zerzová, J. (2011). Teorie a výzkum expertnosti učitelské profese. MuniPress. 
Princlíková, I. (2015). Portfolio na 1. stupni základní školy a práce s ním. Komenský, 139(2), 53-56.

MŠMT. (2017). Rámcové požadavky na studijní programy, jejichž absolvováním se získává odborná kvalifikace $k$ výkonu regulovaných povolání pedagogických pracovníkủ. https://www.msmt. cz/file/44169/

Spilková, V. (Ed.) (2004). Současné proměny vzdělávání učitelů. Paido.

Spilková, V. (2005). Proměny primárního vzdělávání. Praha: Portál.

Spilková, V. (2006). Dilemata v pojetí pedagogické přípravy studentů učitelství. Pedagogika, 56(1), 19-30.

Spilková, V. (2007). Význam portfolia pro profesní rozvoj studentů učitelství. In M. Píšová (Ed.), Portfolio v profesní př́pravě učitele (s. 7-19). Univerzita Pardubice.

Spilková, V. (2019). Přístupy k výuce pedagogiky v kontextu měnících se paradigmat v učitelském vzdělávání. Pedagogika, 69(3), 269-291.

Stuchlíková, I. (2006). Role implicitních procesů při utváření profesní identity budoucích učitelů. Pedagogika, 55(1), 31-44.

Stuchlíková, I., \& Janík, T. (2017). Rámcová koncepce př́ípravného vzdělávání učitelů aneb O hledání a nacházení konsensu mezi aktéry. Pedagogická orientace, 27(1), 243-266.

Svatoš, T. (2006). Studentské portfolio jako zdroj poznání postoje začínajících studentů učitelství. Pedagogika, 56(1), 45-57.

Sylva, K., Melhuish, E., Sammons, P., Siraj-Blatchford, I., \& Taggart, B. (2004). The Effective Provision of Pre-school Education (EPPE) Project: Findings from pre-school to end of key stage 1. United Kingdom: Department for Education and Skills.

Syslová, Z. (2015). The level of reflection in the professional development of pre-primary teachers. Przeglad Pedagogczny, 9(1), 73-84.

Syslová, Z. (2016). Rozvoj profesního vidění studentů oboru Učitelství pro mateřské školy. Pedagogika, 66(4), 440-454.

Syslová, Z. (2017). Učitel v předškolním vzdělávání a jeho př́prava na profesi. MuniPress.

Syslová, Z., Píšová, M., Rodová, V., Černá, M., Grůzová, L., Nováková, E., \& Stadlerová, H. (2018a). Podpora tvorby profesního portfolia $v$ př́pravném vzdělávání učitelů mateřských škol a 1. stupně základních škol. Masarykova univerzita.

Syslová, Z., Píšová, M., Rodová, V., Grůzová, L., \& Stadlerová, H. (2018b). Profesní portfolio $v$ př́pravném vzdělávání učitelů mateřských škol a 1. stupně základních škol. Masarykova univerzita.

Syslová, Z., Grůzová, L., \& Štěpánková, L. (2019). Podpora vedení studentů na praxi v mateřské škole. Masarykova univerzita.

Štech, S. (1999). Teoretické přístupy k vysokoškolské výuce. In J. Vašutová (Ed.), Vybrané otázky vysokoškolské pedagogiky. Pedagogická fakulta UK.

Švaříček, R., Šedová, K., Janík, T., Kaščák, O., Miková, M., Nedbálková, K., Novotný, P., Sedláček, M., \& Zounek, J. (2007). Kvalitativní výzkum v pedagogických vědách. Portál.

Švec, V., Cásková, K., Jakešová, J., Jašková, J., Koubek, P., Minaříková, E., Svojanovský, P., Šimůnková, B., Vystrčilová, P., Nehyba, J., \& Pravdová, B. (2014). Znalostní báze učitelství. Masarykova univerzita.

Tomková, A. (2018). Portfolio v perspektivě reflektivně pojatého vzdělávání učitelů. Pedagogická fakulta UK. 
Tomková, A., \& Spilková, V. (2019). Profesionalizace vzdělávání učitelů pro primární školu možnosti a meze. Orbis scholae, 13(1), 9-29.

Trunda, J. (2012). Profesní portfolio učitele. Národní ústav pro vzdělávání.

Třeštík, D. (1997). Počátky Přemyslovců. NLN s. r. o.

Yoshikawa, H., Weiland, C., Brooks-Gunn, J., Burchinal, M., Espinosa, L., Gormley, W. T., Ludwig, J., Magnuson, K., Phillips, D., \& Zaslow, M. (2013). Investing in our future: The evidence base on preschool education. Society for Research in Child Development.

Václavík, A. (2014). Portfolio: př́běh učení žáka. Komenský, 139(2), 23-27.

Vašutová, J. (2002). Strategie výuky ve vysokoškolském vzdělávání. PdF UK.

Wyatt, R. L., \& Looper, S. (1999). So you have to have a portfolio. A teacher's guide to preparation and presentation. Corwin Press.

\title{
Autorky
}

doc. PhDr. Zora Syslová, Ph.D. Masarykova univerzita, Pedagogická fakulta, Katedra primární pedagogiky, Poříčí 31, 60300 Brno, e-mail: syslova@ped.muni.cz

Mgr. Veronika Rodová, Ph.D., Masarykova univerzita, Pedagogická fakulta, Katedra primární pedagogiky, Poříćí 31, 60300 Brno, e-mail: rodova@ped.muni.cz

\section{Professional identity of pre-service kindergarten teachers and its reflection in their portfolios}

\begin{abstract}
The study provides an insight into the portfolio and its place in the reflectively conceived pre-service teacher training of kindergarten teachers at the Faculty of Education of Masaryk University. The aim of the study was to contribute to the discussion on the professionalisation concept in the training of the future preschool teachers using action research of teaching strategies and their influence upon the professional development of the students. The introductory part of the study is devoted to the theory of teacher education and analysis of the key concept of the portfolio, which is based on an overview study of Czech and foreign sources. The core of the study is action research aimed at monitoring the impact of the course Creating a Professional Portfolio on the development of the professional identity of students. The results of the study show how collaborative activities and peer assessment develop interpersonal skills in the students, encourage their self-confidence and deepen their understanding of the function of portfolio as the tool for self-expression and professional growth. In addition to action research, the study provides four individualised portraits of female students who used portfolios in the final state exams.
\end{abstract}

Keywords: portfolio, student, reflective pre-service teacher education, professional development, action research, socio-constructivism 